\title{
27. NATURAL PHASE EQUILIBRIA AND PETROLOGIC MODELS: LAU BASIN SITES 834, 836, AND 8391
}

\author{
W.B. Bryan, ${ }^{2}$ A. Ewart,${ }^{3}$ T.L. Grove,${ }^{4}$ and T.H. Pearce ${ }^{5}$
}

\begin{abstract}
We use a combination of graphic projections for exploratory interpretation of natural phase equilibria and liquid lines of descent. The data used are original shipboard X-ray fluorescence (XRF) analyses, supplemented by additional XRF analyses completed on shore, microprobe analyses of minerals in key samples, and microprobe data for glasses. Good agreement exists in the data groupings and trends between the projections used (CMAS, Al-Fe, and Pearce plots). The natural phase assemblages in the rock samples are consistent in most cases with those predicted by the graphically projected phase boundaries and liquid lines of descent, suggesting a major role for crystal-melt equilibria in the evolution of these rocks. This assumption is further tested with materials balance calculations and by analogy to experimental phase equilibria studies on a sample from Hole $839 \mathrm{~B}$. Shifts in graphic projections of inferred phase boundaries resemble those obtained experimentally at elevated pressure water-saturated, as detailed elsewhere in this volume. Materials-balance calculations yield excellent fits for most major element oxides. This provides strong support for inferred fractionation models, which imply "wet" equilibria for several subsets of the data. However, trace element variations in some data subsets are difficult to equate with the models, based on major element data, and appear to require heterogeneity in melt sources and/or in the trace element signatures of possible xenocrystal phases. It is also possible that the distribution coefficients usually assumed for "dry" systems are significantly altered under the high water contents inferred for these magmas.
\end{abstract}

\section{INTRODUCTION}

Lau Basin Sites 834,836 , and 839 each contain a range of compositions, from basalt or basaltic andesite to variously evolved andesitic rocks. This paper reports the results of exploratory interpretation of possible petrogenetic relations within and between drill sites. Specifically, we examine the extent to which these relations can be explained by crystal-melt equilibria. Bulk-rock and natural glass compositions from these sites follow systematic trends in several graphic analogs to phase diagrams that are highly suggestive of liquid lines of descent controlled by crystal-melt equilibria. Subtle differences between trends, and the offset of some trends from the typical 1-atm. phase boundaries established for mid-ocean-ridge basalt (MORB) and mafic island arc lavas suggests the possible influence of variations in pressure and/or volatile content on phase equilibria in these backarc lavas. An important role for volatiles, presumably largely water, is also suggested by the very high vesicularity of these rocks, which in some cases exceeds 30 vol\% (Parson, Hawkins, Allan, et al., 1992).

In this paper we present additional bulk-rock X-ray fluorescence (XRF) data and initial microprobe data on selected rock samples to test more rigorously these possible relationships, originally suggested by shipboard studies. We emphasize that these investigations are still exploratory in nature, and that our results require further integration with other trace element and isotope data.

\section{DATA SOURCES AND LIMITATIONS}

The $20 \mathrm{XRF}$ analyses for major elements and selected trace elements conducted at Woods Hole are presented in Tables 1 and 2.

\footnotetext{
'Hawkins, J., Parson, L., Allan, J., et al., 1994. Proc. ODP, Sci. Results, 135: College Station, TX (Ocean Drilling Program).

${ }^{2}$ Department of Geology and Geophysics, Woods Hole Oceanographic Institution. Woods Hole, MA 02543 , U.S.A.

${ }^{3}$ Department of Geology and Mineralogy, University of Queensland, St. Lucia, Brisbane 4067 , Australia.

${ }^{4}$ Department of Earth and Planetary Science, Massachusetts Institute of Technology. Cambridge, MA 02139, U.S.A.

${ }^{5}$ Department of Geology, Queen's University, Kingston, Ontario, K7L 3N6, Canada.
}

The methodology has been described by Schroeder et al. (1980). Our standards and correction procedures are generally similar to those used on shipboard (Sims and Hergt, this volume), so it is not surprising that the new analyses are very similar to shipboard analyses from the same lithologic units. This further confirms the consistency between lithology and chemistry noted in the Initial Reports volume (Parson, Hawkins, Allan, et al., 1992). These analyses were combined with those completed on board the JOIDES Resolution and were grouped and averaged by lithologic units. The correlations between lithology and chemistry have also been confirmed by microprobe analyses of natural rock glasses for those units for which glass was available (Hergt and Nilsson, this volume). The Woods Hole and shipboard XRF data have been used interchangeably for graphic interpretation and materials balance calculations. The glass data, as shown below, may plot in groups distinct from the bulk-rock data. In such cases, the glasses are always more evolved in composition (higher in $\mathrm{SiO}_{2}, \mathrm{FeO}, \mathrm{Na}_{2} \mathrm{O}$, and $\mathrm{K}_{2} \mathrm{O}$ ) than the corresponding bulk rock. This relation is not unexpected, as it has also been observed in phyric MORB (Bryan et al., 1981; Tormey et al., 1987). This generally precludes a direct comparison of XRF and glass data, although the agreement is generally good for most aphyric units. However, materials balance calculations that use both XRF and glass data very commonly show misfits for $\mathrm{Na}_{2} \mathrm{O}$ even where all other elements are well matched, suggesting a possible systematic difference between the XRF and microprobe $\mathrm{Na}_{2} \mathrm{O}$ data. Comparisons of glass to corresponding aphyric rock also show that the XRF data are consistently lower in $\mathrm{Na}_{2} \mathrm{O}$ than the glass.

Electron microprobe analyses of selected minerals (Table 3) were conducted on the automated 4-spectrometer JEOL microprobe at the Massachusetts Institute of Technology. Analytical conditions are described by Gaetani et al. (this volume). We used backscatter images to check for heterogeneity (usually slight) and, in most cases, did short core-to-rim traverses to confirm the nature and extent of zoning in typical phenocrysts, xenocrysts, and microphenocrysts. The hindsight provided by subsequent materials-balance calculations suggests that the "representative" samples selected for analysis did not quite cover the range of phases and phase compositions likely to be involved in fractionation schemes in this large and rather complex data set. We comment on these cases at the appropriate point in the following discussions. 
Table 1. XRF major element data, Sites $834,835,836,839$, and 841 .

\begin{tabular}{|c|c|c|c|c|c|c|c|c|c|c|c|}
\hline $\begin{array}{l}\text { Core section, } \\
\text { interval }(\mathrm{cm})\end{array}$ & $\mathrm{SiO}_{2}$ & $\mathrm{TiO}_{2}$ & $\mathrm{Al}_{2} \mathrm{O}_{3}$ & FeOT & $\mathrm{MnO}$ & $\mathrm{MgO}$ & $\mathrm{CaO}$ & $\mathrm{Na}_{2} \mathrm{O}$ & $\mathrm{K}_{2} \mathrm{O}$ & $\mathrm{P}_{2} \mathrm{O}_{5}$ & Total \\
\hline $\begin{array}{l}\text { Unit 5: } \\
\text { 135-834B-13R-1, 130-131 }\end{array}$ & 50.05 & 1.11 & 16.85 & 8.02 & 0.14 & 8.63 & 11.44 & 2.82 & 0.14 & 0.12 & 99.32 \\
\hline $\begin{array}{l}\text { Unit 7: } \\
\text { 135-834B-20R-1, 70-74 } \\
\text { 135-834B-22R-2, 24-28 } \\
\text { 135-834B-25R-1, 106-110 } \\
\text { 135-834B-30R-2, 128-132 } \\
\text { 135-834B-31R-2, 72-76 } \\
\text { 135-834B-33R-2, 105-110 } \\
\text { 135-834B-33R-4, 129-133 } \\
\text { 135-834B-34R-1, 76-80 } \\
\text { Unit 7 average }\end{array}$ & $\begin{array}{l}50.54 \\
50.38 \\
50.08 \\
49.61 \\
49.65 \\
49.45 \\
49.42 \\
49.45 \\
49.82\end{array}$ & $\begin{array}{l}1.32 \\
1.29 \\
1.26 \\
1.24 \\
1.24 \\
1.23 \\
1.21 \\
1.17 \\
1.24\end{array}$ & $\begin{array}{l}17.66 \\
17.56 \\
18.39 \\
17.99 \\
17.92 \\
17.94 \\
18.11 \\
18.46 \\
18.00\end{array}$ & $\begin{array}{l}7.83 \\
7.69 \\
7.39 \\
7.78 \\
7.72 \\
7.70 \\
7.65 \\
7.47 \\
7.65\end{array}$ & $\begin{array}{l}0.13 \\
0.12 \\
0.13 \\
0.13 \\
0.13 \\
0.14 \\
0.13 \\
0.12 \\
0.13\end{array}$ & $\begin{array}{l}6.83 \\
7.68 \\
6.85 \\
7.96 \\
8.00 \\
8.01 \\
8.01 \\
8.00 \\
7.67\end{array}$ & $\begin{array}{l}12.24 \\
11.98 \\
12.93 \\
12.15 \\
12.13 \\
11.70 \\
12.22 \\
12.14 \\
12.19\end{array}$ & $\begin{array}{l}3.06 \\
2.85 \\
2.79 \\
2.82 \\
2.79 \\
2.87 \\
2.79 \\
2.92 \\
2.86\end{array}$ & $\begin{array}{l}0.18 \\
0.06 \\
0.14 \\
0.09 \\
0.08 \\
0.09 \\
0.09 \\
0.09 \\
0.10\end{array}$ & $\begin{array}{l}0.13 \\
0.13 \\
0.13 \\
0.13 \\
0.13 \\
0.13 \\
0.13 \\
0.13 \\
0.13\end{array}$ & $\begin{array}{r}99.92 \\
99.74 \\
100.09 \\
99.91 \\
99.78 \\
99.26 \\
99.74 \\
99.96 \\
99.80\end{array}$ \\
\hline $\begin{array}{l}\text { Unit 1: } \\
\text { 135-835B-5R-1, 22-26 } \\
\text { 135-835B-7R-2, 75-84 } \\
\text { Unit I average }\end{array}$ & $\begin{array}{l}50.94 \\
51.65 \\
51.30\end{array}$ & $\begin{array}{l}0.91 \\
0.84 \\
0.87\end{array}$ & $\begin{array}{l}16.47 \\
16.21 \\
16.34\end{array}$ & $\begin{array}{l}8.61 \\
8.26 \\
8.43\end{array}$ & $\begin{array}{l}0.17 \\
0.13 \\
0.15\end{array}$ & $\begin{array}{l}7.69 \\
8.19 \\
7.94\end{array}$ & $\begin{array}{l}12.92 \\
12.65 \\
12.78\end{array}$ & $\begin{array}{l}2.10 \\
2.14 \\
2.12\end{array}$ & $\begin{array}{l}0.30 \\
0.13 \\
0.22\end{array}$ & $\begin{array}{l}0.10 \\
0.08 \\
0.09\end{array}$ & $\begin{array}{l}100.20 \\
100.28 \\
100.24\end{array}$ \\
\hline $\begin{array}{l}\text { Unit 1: } \\
\qquad 135-836 \mathrm{~A}-3 \mathrm{H}-3,33-43\end{array}$ & 55.39 & 1.32 & 14.76 & 11.99 & 0.21 & 4.05 & 8.48 & 3.00 & 0.26 & 0.14 & 99.60 \\
\hline $\begin{array}{l}\text { Unit 2: } \\
\quad 135-836 \mathrm{~A}-3 \mathrm{H}-4,88-100\end{array}$ & 56.60 & 1.18 & 14.50 & 11.32 & 0.26 & 3.77 & 8.18 & 3.18 & 0.29 & 0.14 & 99.42 \\
\hline $\begin{array}{l}\text { Unit 4: } \\
\qquad 135-836 \mathrm{~A}-9 \mathrm{X}-1,138-143\end{array}$ & 49.42 & 0.79 & 16.75 & 7.76 & 0.13 & 9.43 & 13.80 & 2.09 & 0.07 & 0.06 & 100.28 \\
\hline $\begin{array}{l}\text { Subunit 4B: } \\
\quad 135-836 \mathrm{~B}-5 \mathrm{R}-2,65-74\end{array}$ & 49.12 & 0.76 & 15.68 & 8.27 & 0.14 & 9.78 & 13.80 & 1.86 & 0.06 & 0.06 & 99.53 \\
\hline 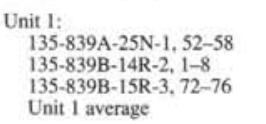 & $\begin{array}{l}51.93 \\
53.59 \\
52.35 \\
52.62\end{array}$ & $\begin{array}{l}0.61 \\
0.65 \\
0.63 \\
0.64\end{array}$ & $\begin{array}{l}15.02 \\
15.34 \\
15.05 \\
15.14\end{array}$ & $\begin{array}{l}8.61 \\
8.48 \\
8.83 \\
8.63\end{array}$ & $\begin{array}{l}0.16 \\
0.17 \\
0.17 \\
0.17\end{array}$ & $\begin{array}{l}9.31 \\
8.18 \\
9.46 \\
8.98\end{array}$ & $\begin{array}{l}12.03 \\
11.86 \\
11.56 \\
11.82\end{array}$ & $\begin{array}{l}1.52 \\
1.57 \\
1.47 \\
1.52\end{array}$ & $\begin{array}{l}0.24 \\
0.28 \\
0.24 \\
0.25\end{array}$ & $\begin{array}{l}0.08 \\
0.08 \\
0.07 \\
0.08\end{array}$ & $\begin{array}{r}99.53 \\
100.19 \\
99.83 \\
99.85\end{array}$ \\
\hline $\begin{array}{l}\text { Unit 3: } \\
\text { 135-839B-24R-1, 14-19 }\end{array}$ & 49.60 & 0.52 & 11.45 & 8.98 & 0.16 & 17.58 & 9.68 & 1.34 & 0.29 & 0.07 & 99.66 \\
\hline $\begin{array}{l}\text { Subunit 3C: } \\
\quad 135-841 B-54 R-2,142-146\end{array}$ & 76.31 & 0.34 & 12.43 & 3.38 & 0.03 & 1.81 & 1.32 & 3.85 & 0.68 & 0.06 & 100.19 \\
\hline
\end{tabular}

Table 2. Trace elements by X-ray fluorescence analysis for Sites $834,835,836,839$, and 841 .

\begin{tabular}{|c|c|c|c|c|c|c|c|c|c|c|c|}
\hline $\begin{array}{l}\text { Core, section, } \\
\text { interval }(\mathrm{cm})\end{array}$ & $\mathrm{Zr}$ & $\mathrm{Y}$ & $\mathrm{Sr}$ & $\mathrm{Rb}$ & $\mathrm{Zn}$ & $\mathrm{Cu}$ & $\mathrm{Ni}$ & $\mathrm{Cr}$ & Co & $\mathrm{Ba}$ & V \\
\hline \multicolumn{12}{|l|}{$135-834 \mathrm{~B}-$} \\
\hline $13 \mathrm{R}-1,130-138$ & 86 & 25.6 & 161 & 2.1 & 62 & 75 & 106 & 189 & 48 & 46 & 225 \\
\hline $33 R-2,105-110$ & 97 & 26.1 & 156 & 1.7 & 57 & 65 & 100 & 264 & 46 & 14 & 208 \\
\hline $20 \mathrm{R}-1,70-74$ & 97 & 28.7 & 159 & 3.2 & 65 & 69 & 115 & 295 & 42 & 8 & 224 \\
\hline $22 \mathrm{R}-2,24-28$ & 98 & 29.2 & 146 & 1.6 & 62 & 65 & 112 & 269 & 46 & 13 & 208 \\
\hline $25 \mathrm{R}-1,106-110$ & 96 & 27.9 & 161 & 2.6 & 64 & 67 & 121 & 309 & 42 & 13 & 210 \\
\hline $30 \mathrm{R}-2,128-132$ & 101 & 27.1 & 159 & 1.5 & 58 & 63 & 96 & 274 & 43 & 9 & 203 \\
\hline $31 R-2,72-76$ & 98 & 27.1 & 154 & 1.4 & 57 & 62 & 102 & 290 & 44 & 11 & 205 \\
\hline $33 \mathrm{R}-4,129-133$ & 98 & 26.7 & 154 & 1.3 & 56 & 63 & 103 & 248 & 43 & 7 & 188 \\
\hline $34 \mathrm{R}-1,76-80$ & 97 & 25.8 & 158 & 1.4 & 56 & 61 & 99 & 262 & 44 & 6 & 186 \\
\hline \multicolumn{12}{|l|}{$135-835 \mathrm{~B}-$} \\
\hline $5 R-1,22-26$ & 44 & 24.0 & 134 & 6.2 & 72 & 84 & 79 & 165 & 48 & 20 & 270 \\
\hline $7 R-2,75-84$ & 43 & 23.6 & 131 & 2.7 & 76 & 78 & 79 & 121 & 49 & 46 & 246 \\
\hline \multicolumn{12}{|l|}{$135-836 \mathrm{~A}-$} \\
\hline $3 \mathrm{H}-3,33-43$ & 73 & 34.0 & 147 & 5.9 & 97 & 110 & 21 & 10 & 49 & 58 & 422 \\
\hline $3 \mathrm{H}-4,88-100$ & 77 & 35.9 & 147 & 6.8 & 96 & 124 & 22 & 8 & 46 & 85 & 367 \\
\hline $5 R-2,65-74$ & 41 & 19.5 & 137 & 1.7 & 62 & 110 & 107 & 213 & 49 & 2 & 239 \\
\hline $9 X-1,138-143$ & 44 & 19.8 & 142 & 1.8 & 53 & 99 & 124 & 308 & 51 & 2 & 248 \\
\hline \multicolumn{12}{|l|}{$135-839 \mathrm{~A}-$} \\
\hline $25 \mathrm{~N}-1,52-58$ & 28 & 16.8 & 147 & 6.6 & 69 & 82 & 126 & 636 & 44 & 47 & 292 \\
\hline \multicolumn{12}{|l|}{$135-839 \mathrm{~B}-$} \\
\hline $14 R-2,1-8$ & 28 & 17.2 & 156 & 10.4 & 59 & 89 & 101 & 313 & 42 & 60 & 284 \\
\hline $15 \mathrm{R}-3,72-76$ & 25 & 15.3 & 152 & 5.3 & 60 & 75 & 137 & 368 & 46 & 62 & 298 \\
\hline $24 \mathrm{R}-1,14-19$ & 32 & 14.7 & 120 & 6.8 & 67 & 76 & 477 & 1696 & 65 & 36 & 228 \\
\hline \multicolumn{12}{|l|}{$135-841 \mathrm{~B}-$} \\
\hline $54 \mathrm{R}-2,142-146$ & 148 & 53.2 & 72 & 7.0 & 27 & 25 & 7 & 7 & 13 & 342 & 33 \\
\hline
\end{tabular}

\section{MINERALOGY}

Our immediate objective has been to document variations in natural phase compositions for comparison to experimental phase assemblages (Gaetani et al, this volume); to support studies of plagioclase zoning; and to provide the basic data needed to test simple fractionation models. Plagioclase and olivine analyses from Hole 834B are presented and discussed by Bryan and Pearce (this volume); here, we summarize and interpret these and additional data that we obtained from Holes 836A and 839B. We will emphasize compositional features that have been taken into account in formulating the model fractionation assemblages discussed later in this paper. To facilitate 
comparison of compositions both within and between individual crystals, we have graphed compositional variation for each crystal in sequence from core to rim, using an arbitrary horizontal scale.

\section{Plagioclase}

Some typical plagioclase composition profiles are shown in Figure 1, complete analyses are presented in Table 3 as well as in Tables 1 and 2 of Bryan and Pearce (this volume). Grain B1 is from an andesitic rock (135-836A-9X-1, 138-143 cm, Unit 4) and is a rim-core-rim profile across a small microphenocryst. Grains $\mathrm{C} 1$ and D1 are from a Unit 2 andesite in Sample 135-839B-35R-1, 57-59 cm. Grains E1 and F1 are also from Hole 839B, but they are from Sample 135-839B$18 \mathrm{R}-1,18-23 \mathrm{~cm}$, within a Unit 2 andesite. Notable features are the much higher anorthite content and more limited zoning to sodic compositions in the two Hole 839B units, in comparison with Hole 836A.

Also of interest is the behavior of $\mathrm{Fe}$ and $\mathrm{Mg}$ relative to anorthite. Bryan (1974) showed that $\mathrm{FeO}$ and $\mathrm{MgO}$ in calcic MORB plagioclase generally increase with albite content, in part because they apparently occupy an albite-like structure in the crystal. But in Hole $836 \mathrm{~A}, \mathrm{MgO}$ (and $\mathrm{Mg \# )}$ are positively correlated with anorthite, whereas $\mathrm{FeO}$ varies relatively little. In the two Hole $839 \mathrm{~B}$ andesites, both $\mathrm{MgO}$ and $\mathrm{FeO}$ show the expected strong negative correlation with anorthite, although little change takes place in the $\mathrm{Mg \#}$. This suggests that the plagioclase in the Hole $836 \mathrm{~A}$ andesite coprecipitated with a phase such as olivine, which was depleting the melt in $\mathrm{MgO}$, and also that there may have been concurrent iron depletion caused by crystallization of an Fe-bearing oxide. In contrast, the Hole 839B plagioclases crystallized in an environment in which the magmatic $\mathrm{Mg \#}$ and total $\mathrm{MgO}$ and $\mathrm{FeO}$ contents changed relatively little. This is an effect that might be expected during crystallization at or near an olivinepyroxene reaction point, where $\mathrm{Fe}$ and $\mathrm{Mg}$ are redistributed among new phases but little immediate change occurs in the overall $\mathrm{Mg} / \mathrm{Fe}$ ratio in the magma.

\section{Pyroxenes}

Many of the clinopyroxenes in these rocks show wavy, irregular extinction and some are sector zoned. As a result, few show simple core-rim profiles, and many grains are too small for extended traverses. Electron microprobe analyses are given in Table 3. In Figure 2, we compare some typical clinopyroxenes from four different lithologic units, as indicated. $\mathrm{Ca}, \mathrm{Mg}$, and $\mathrm{Fe}$ are expressed as ternary end-members in molar percent to facilitate classification. Cores of all grains are high-Ca and close to the boundary between endiopside and augite; in this they are similar to the clinopyroxenes produced in "wet" experiments (Gaetani et al., this volume). Grain A in Hole 836A was large enough for a rim-core-rim traverse; it also proved to be sectorzoned, which accounts for the peculiar symmetrical sawtooth pattern of most components. In Hole 839B, the clinopyroxenes in the two andesite units are very similar and appear to be quite uniform in composition except for the more Fe-rich outer zones, as in Grain C; this suggests a relatively prolonged period of equilibration with the melt before quenching. Clinopyroxenes from the more primitive Unit 3 are much more variable in both major and minor elements, as might be expected if they had been exposed either to varying melt compositions or fluctuating physical conditions during growth. This could be a result of magma mixing and may account for difficulties, discussed later, in reconciling trace element data with a simple cumulate model for Unit 3.

All of the analyzed orthopyroxenes (Table 3) are from andesite Units 2 and 9 in Hole 839B (Fig. 3). These small grains are each represented by $3-5$ point analyses; these are not core-to-rim profiles as in the clinopyroxenes, but the plots do allow comparison of variation within and between grains. For the most part, a similar range of compositions is present in both units, but the $\mathrm{Al} 2 \mathrm{O} 3$ in the Unit 2 orthopyroxene is significantly higher.

\section{Olivine}

Olivines in Hole 836A, Unit 4, occur as discrete rounded grains about $0.4 \mathrm{~mm}$ in diameter, which, like the many small plagioclase laths, may be ophitically enclosed by clinopyroxene. Electron microprobe analyses are given in Table 3 . A core-rim profile of one of these is Grain A in Figure 4A. In our sample from Hole 839B, Unit 3, two contrasting olivine morphologies were present. One consists of large, rounded grains with an irregular outline that are commonly fractured and appear to be in the process of breaking up. These large crystals may contain kink bands and inclusions of red-brown spinel. It is tempting to think of them as mantle xenocrysts. The second type of olivine consists of irregular, often angular groundmass grains surrounded by a cryptocrystalline matrix. Backscatter images with the microprobe did not indicate any substantial zoning in the large crystals, nor much difference between these and the groundmass olivine. To check this, we analyzed several points within a large "xenocryst" (Grain B) and one or two points each on different angular groundmass olivines (Grains $\mathrm{C}-\mathrm{G}$ ). These analyses confirm the general similarity between the olivines; and this, along with the breccia-like groundmass texture, suggests that Unit 3 may be, in part, a preexisting cumulate unit that has been broken and deformed. The minor element components in these olivines are apparently not as variable as in the clinopyroxenes; this may be caused by the fact that the clinopyroxenes are not fragments but appear to be true magmatic precipitates; therefore, their compositions could reflect inhomogeneous distribution of elements such as $\mathrm{Ni}$ and $\mathrm{Cr}$ derived by assimilation of the disintegrating cumulate assemblage.

The olivines in Hole 834B, Unit 7 (Fig. 4B) were analyzed in part to help confirm the apparent subtle change in magma composition from the top to the bottom of Unit 7 (Bryan and Pearce, Table 3, this volume). A small increase is present in Fo, and a slight decrease in $\mathrm{CaO}$, consistent with the bulk chemical changes in the unit. The change in $\mathrm{NiO}$ is more ambiguous, although it is clearly higher in the lowest grain $(\mathrm{U})$ compared with the uppermost one $(\mathrm{P})$.

\section{COMPARISON OF GRAPHIC PROJECTIONS}

\section{Projections in CMAS}

In the $\mathrm{CMAS}\left(\mathrm{CaO}-\mathrm{MgO}-\mathrm{Al}_{2} \mathrm{O}_{3}-\mathrm{SiO}_{2}\right)$ projection from plagioclase (Fig. 5), bulk-rock samples and their corresponding glasses are grouped and plotted according to their phenocryst phase assemblages observed in thin section. The solid phase boundaries shown are based on 1-atm. crystallization experiments on MORB (Walker et al., 1979; Grove and Bryan, 1983; Grove and Kinzler, 1986). It shows the liquid line of descent, or cotectic boundary, in this projection for samples multiply saturated in olivine and clinopyroxene; plagioclase saturation also is assumed. Olivine is replaced by low-Ca pyroxene at the reaction point indicated by the bifurcation of the line toward the Qtz (silica) apex. The offset dashed lines show schematically the direction of shift of the phase boundaries with increasing pressure; a similar shift is also produced as water content of the melt increases. At about $2 \mathrm{Kbar}$ and $6 \% \mathrm{H}_{2} \mathrm{O}$ olivine is first replaced by very calcic clinopyroxene, which is later joined by orthopyroxene (Gaetani et al., this volume). At Site 834 , for which we have the largest number of samples, most of the data define a linear band close to and paralleling the olivine-clinopyroxene phase boundary (Fig. 5A). The clinopyroxene-phyric samples most closely conform to the 1-atm. boundary; the more primitive samples (largely Units 7 and 5) are olivine-plagioclase phyric and are offset toward the olivine-clinopyroxene join. The implied undersaturation in silica is mostly because all the $\mathrm{Fe}$ has been calculated as $\mathrm{FeO}$, so that all the Fe appears as silicate rather than partly as oxide. The most evolved samples are the glasses associated with the andesitic lavas of Units 10 and 12. These are offset toward the high pressure side of the 1-atm. boundary. As discussed in more detail by Gaetani et al. (this volume), such a shift can be produced by increased pressure, by increased water content, or by these two effects combined. Except for 
Table 3. Electron microprobe analyses of plagioclase, clinopyroxene, orthopyroxene, olivine, and spinel, Holes 836A and 839B.

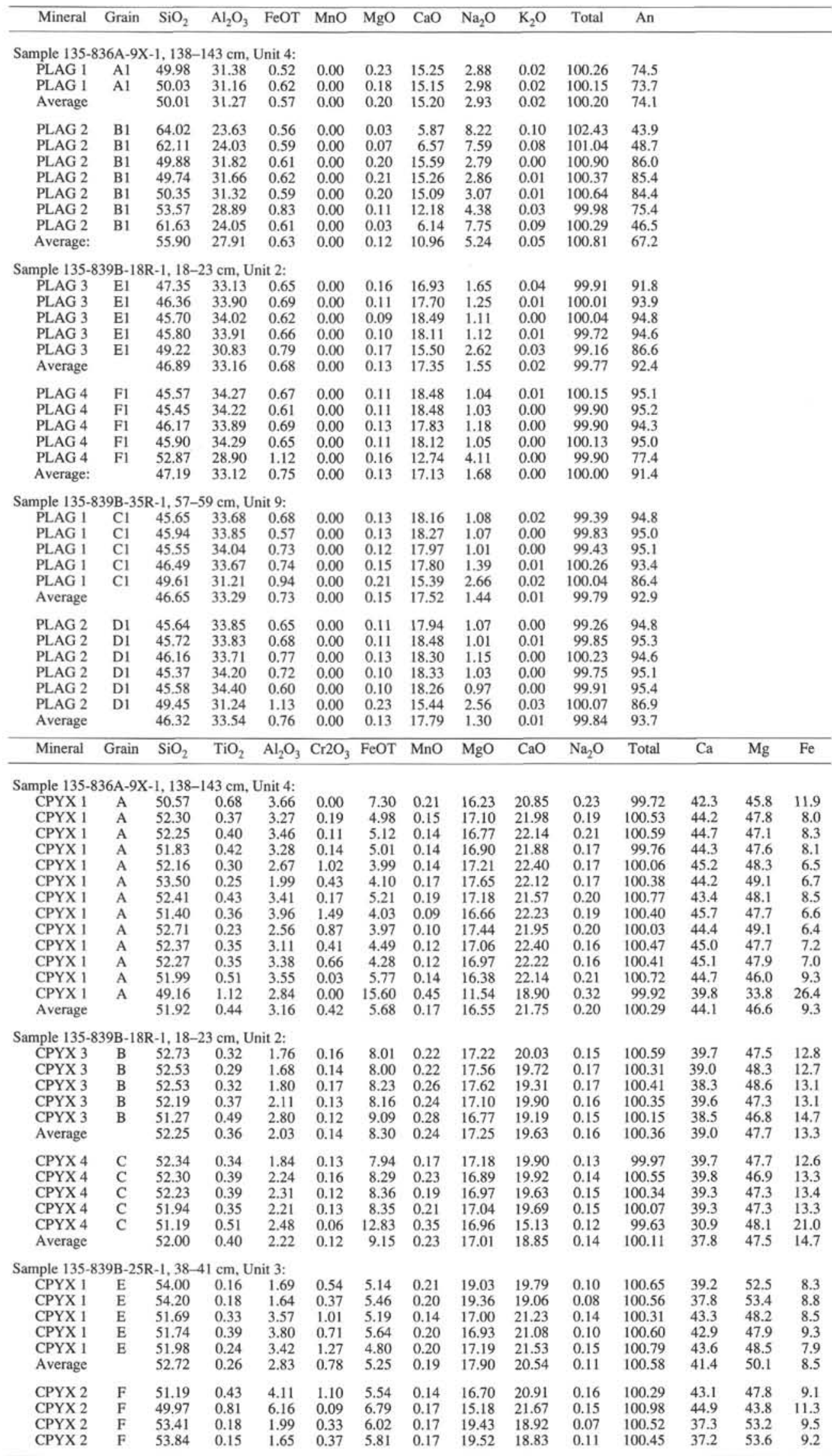


Table 3 (continued).

\begin{tabular}{|c|c|c|c|c|c|c|c|c|c|c|c|c|c|c|}
\hline Mineral & Grain & $\mathrm{SiO}_{2}$ & $\mathrm{TiO}_{2}$ & $\mathrm{Al}_{2} \mathrm{O}_{3}$ & $\mathrm{Cr}_{2} \mathrm{O}_{3}$ & $\mathrm{FeOT}$ & $\mathrm{MnO}$ & $\mathrm{MgO}$ & $\mathrm{CaO}$ & $\mathrm{Na}_{2} \mathrm{O}$ & Total & $\mathrm{Ca}$ & $\mathrm{Mg}$ & $\mathrm{Fe}$ \\
\hline CPYX 2 & F & 51.15 & 0.50 & 4.54 & 1.02 & 5.46 & 0.16 & 16.47 & 20.97 & 0.18 & 100.45 & 43.4 & 47.5 & 9.1 \\
\hline Average & & 51.91 & 0.41 & 3.69 & 0.58 & 5.93 & 0.16 & 17.46 & 20.26 & 0.13 & 100.54 & 41.2 & 49.2 & 9.7 \\
\hline \multicolumn{15}{|c|}{ Sample $135-839 \mathrm{~B}-35 \mathrm{R}-1,57-59 \mathrm{~cm}$, Unit 9: } \\
\hline CPYX 1 & $\mathrm{~J}$ & 52.43 & 0.29 & 1.75 & 0.13 & 7.72 & 0.25 & 17.61 & 19.58 & 0.15 & 99.90 & 38.9 & 48.7 & 12.4 \\
\hline CPYX 1 & $\mathrm{~J}$ & 52.49 & 0.33 & 2.16 & 0.21 & 7.36 & 0.24 & 17.18 & 20.24 & 0.15 & 100.36 & 40.4 & 47.7 & 11.8 \\
\hline CPYX 1 & J & 51.19 & 0.46 & 3.48 & 0.16 & 8.49 & 0.25 & 16.31 & 20.06 & 0.17 & 100.57 & 40.5 & 45.8 & 13.8 \\
\hline Average & & 52.04 & 0.36 & 2.46 & 0.16 & 7.85 & 0.25 & 17.03 & 19.96 & 0.16 & 100.28 & 39.9 & 47.4 & 12.7 \\
\hline CPYX 2 & K & 52.38 & 0.34 & 1.94 & 0.13 & 7.73 & 0.24 & 17.16 & 19.80 & 0.14 & 99.84 & 39.7 & 47.8 & 12.5 \\
\hline CPYX 2 & $\mathrm{~K}$ & 52.43 & 0.33 & 1.91 & 0.15 & 7.68 & 0.17 & 16.93 & 20.48 & 0.16 & 100.23 & 40.8 & 46.9 & 12.2 \\
\hline CPYX 2 & K & 52.56 & 0.30 & 1.81 & 0.17 & 7.71 & 0.21 & 17.03 & 20.29 & 0.16 & 100.25 & 40.4 & 47.2 & 12.3 \\
\hline CPYX 2 & $\mathrm{~K}$ & 52.21 & 0.34 & 2.12 & 0.15 & 7.79 & 0.11 & 16.89 & 20.18 & 0.17 & 99.95 & 40.5 & 47.1 & 12.4 \\
\hline CPYX 2 & $\mathrm{~K}$ & 52.00 & 0.35 & 2.13 & 0.17 & 7.83 & 0.20 & 16.82 & 20.65 & 0.15 & 100.28 & 41.0 & 46.5 & 12.5 \\
\hline Average & & 52.32 & 0.33 & 1.98 & 0.15 & 7.75 & 0.18 & 16.97 & 20.28 & 0.15 & 100.11 & 40.5 & 47.1 & 12.4 \\
\hline \multicolumn{15}{|c|}{ Sample $135-839 \mathrm{~B}-18 \mathrm{R}-1,18-23 \mathrm{~cm}$, Unit 2: } \\
\hline OPYX 5 & B & 52.87 & 0.31 & 2.63 & 0.07 & 15.71 & 0.34 & 26.25 & 2.29 & 0.04 & 100.52 & 4.5 & 71.1 & 24.4 \\
\hline OPYX 5 & B & 53.19 & 0.31 & 2.48 & 0.08 & 15.51 & 0.31 & 26.09 & 2.22 & 0.03 & 100.22 & 4.4 & 71.3 & 24.3 \\
\hline OPYX 5 & B & 53.06 & 0.30 & 2.10 & 0.06 & 16.28 & 0.36 & 26.25 & 1.99 & 0.00 & 100.38 & 3.9 & 70.9 & 25.2 \\
\hline Average & & 53.04 & 0.31 & 2.40 & 0.07 & 15.84 & 0.34 & 26.20 & 2.17 & 0.02 & 100.37 & 4.2 & 71.1 & 24.6 \\
\hline OPYX 6 & D & 54.17 & 0.21 & 1.31 & 0.09 & 14.79 & 0.35 & 27.85 & 2.00 & 0.00 & 100.77 & 3.8 & 73.7 & 22.5 \\
\hline OPYX 6 & D & 54.66 & 0.21 & 1.24 & 0.08 & 14.32 & 0.32 & 28.33 & 1.91 & 0.02 & 101.08 & 3.6 & 74.7 & 21.7 \\
\hline OPYX 6 & D & 54.14 & 0.26 & 1.84 & 0.10 & 14.86 & 0.36 & 27.79 & 2.10 & 0.04 & 101.48 & 4.0 & 73.4 & 22.6 \\
\hline Average & & 54.32 & 0.23 & 1.46 & 0.09 & 14.66 & 0.35 & 27.99 & 2.00 & 0.02 & 101.11 & 3.8 & 73.9 & 22.3 \\
\hline \multicolumn{15}{|c|}{ Sample $135-839 \mathrm{~B}-35 \mathrm{R}-1,57-59 \mathrm{~cm}$, Unit 9: } \\
\hline OPYX 1 & G & 54.69 & 0.24 & 1.34 & 0.14 & 14.42 & 0.36 & 28.38 & 1.78 & 0.02 & 101.37 & 3.4 & 74.8 & 21.9 \\
\hline OPYX 1 & G & 55.09 & 0.20 & 0.90 & 0.10 & 14.13 & 0.40 & 28.50 & 1.80 & 0.00 & 101.12 & 3.4 & 75.1 & 21.5 \\
\hline OPYX 1 & G & 55.10 & 0.15 & 0.83 & 0.08 & 14.14 & 0.32 & 28.59 & 1.74 & 0.03 & 100.98 & 3.3 & 75.3 & 21.4 \\
\hline OPYX 1 & G & 54.96 & 0.18 & 0.77 & 0.08 & 14.03 & 0.37 & 28.49 & 1.92 & 0.02 & 100.81 & 3.6 & 75.1 & 21.3 \\
\hline Average & & 54.96 & 0.19 & 0.96 & 0.10 & 14.18 & 0.36 & 28.49 & 1.81 & 0.02 & 101.07 & 3.4 & 75.1 & 21.5 \\
\hline OPYX 2 & H & 54.79 & 0.22 & 1.03 & 0.07 & 14.34 & 0.32 & 28.43 & 1.83 & 0.00 & 101.02 & 3.5 & 75.6 & 20.9 \\
\hline OPYX 2 & H & 55.17 & 0.24 & 1.02 & 0.11 & 14.27 & 0.31 & 28.39 & 1.81 & 0.00 & 101.33 & 3.4 & 74.9 & 21.6 \\
\hline OPYX 2 & $\mathrm{H}$ & 55.31 & 0.16 & 0.73 & 0.10 & 13.91 & 0.33 & 28.87 & 1.84 & 0.03 & 101.28 & 3.5 & 75.6 & 20.9 \\
\hline OPYX 2 & $\mathrm{H}$ & 55.61 & 0.18 & 0.77 & 0.12 & 13.62 & 0.32 & 28.97 & 1.92 & 0.02 & 101.52 & 3.6 & 75.9 & 20.5 \\
\hline Average & & 55.22 & 0.20 & 0.89 & 0.10 & 14.04 & 0.32 & 28.67 & 1.85 & 0.01 & 101.29 & 3.5 & 75.3 & 21.2 \\
\hline OPYX 3 & I & 54.29 & 0.23 & 1.24 & 0.14 & 14.47 & 0.33 & 28.39 & 1.80 & 0.00 & 100.89 & 3.4 & 74.7 & 21.9 \\
\hline OPYX 3 & I & 54.21 & 0.28 & 1.48 & 0.13 & 15.34 & 0.39 & 26.79 & 2.29 & 0.03 & 100.94 & 4.4 & 71.9 & 23.7 \\
\hline OPYX 3 & 1 & 55.53 & 0.19 & 0.90 & 0.06 & 13.83 & 0.36 & 28.91 & 1.86 & 0.02 & 101.66 & 3.5 & 75.7 & 20.8 \\
\hline Average & & 54.68 & 0.23 & 1.21 & 0.11 & 14.55 & 0.36 & 28.03 & 1.98 & 0.02 & 101.17 & 3.8 & 74.1 & 22.1 \\
\hline OPYX 4 & L & 53.0 & 0.26 & 1.52 & 0.13 & 15.63 & 0.34 & 2 & 2.38 & 0.03 & 99. & 4.6 & 71.3 & 24.1 \\
\hline OPYX 4 & L & 54.04 & 0.29 & 1.37 & 0.08 & 15.42 & 0.35 & 27.09 & 2.35 & 0.02 & 101.03 & 4.5 & 72.0 & 23.5 \\
\hline OPYX 4 & L & 54.68 & 0.22 & 1.16 & 0.08 & 14.54 & 0.34 & 28.27 & 1.80 & 0.02 & 101.11 & 3.4 & 74.5 & 22.0 \\
\hline OPYX 4 & $\mathrm{~L}$ & 54.59 & 0.18 & 1.26 & 0.09 & 14.25 & 0.36 & 28.44 & 1.75 & 0.00 & 100.91 & 3.3 & 75.0 & 21.6 \\
\hline OPYX 4 & L & 54.90 & 0.18 & 1.00 & 0.10 & 13.43 & 0.32 & 28.98 & 1.86 & 0.06 & 100.84 & 3.5 & 76.2 & 20.3 \\
\hline Average & & 54.25 & 0.23 & 1.26 & 0.10 & 14.65 & 0.34 & 27.86 & 2.03 & 0.03 & 100.75 & 3.9 & 73.8 & 22.3 \\
\hline Mineral & Grain & $\mathrm{SiO}_{2}$ & $\mathrm{TiO}_{2}$ & $\mathrm{Al}_{2} \mathrm{O}_{3}$ & $\mathrm{Cr}_{2} \mathrm{O}_{3}$ & FeOT & $\mathrm{MnO}$ & $\mathrm{MgO}$ & $\mathrm{CaO}$ & $\mathrm{NiO}$ & Total & Fo & & \\
\hline \multicolumn{15}{|c|}{ Sample 135-836A-9X-1, 138-143 cm, Unit 4: } \\
\hline OLV 2 & A & 40.44 & 0.00 & 0.06 & 0.05 & 13.28 & 0.18 & 46.04 & 0.35 & 0.16 & 100.56 & 85.5 & & \\
\hline OLV 2 & A & 40.59 & 0.00 & 0.07 & 0.03 & 13.65 & 0.27 & 46.52 & 0.38 & 0.18 & 101.68 & 85.2 & & \\
\hline OLV 2 & A & 40. & 0.01 & 0.07 & 0.00 & 13.62 & 0.23 & 45.76 & & 0.12 & 100.69 & 85.1 & & \\
\hline OLV 2 & A & 40.23 & 0.00 & 0.03 & 0.00 & 14.68 & 0.29 & 45.18 & 0.35 & 0.17 & 100.93 & 84.0 & & \\
\hline OLV 2 & A & 39.29 & 0.00 & 0.02 & 0.05 & 20.42 & 0.31 & 41.15 & 0.31 & 0.13 & 101.68 & 77.7 & & \\
\hline $\mathrm{OLV}_{2}$ & A & 35.49 & 0.07 & 0.07 & 0.07 & 39.93 & 0.77 & 24.64 & 0.36 & 0.05 & 101.46 & 51.6 & & \\
\hline Average & & 39.43 & 0.01 & 0.05 & 0.03 & 19.26 & 0.34 & 41.55 & 0.35 & 0.13 & 101.17 & 78.6 & & \\
\hline \multicolumn{15}{|c|}{ Sample 135-839B-25R-1, 38-41 cm, Unit 3: } \\
\hline OLV 1 & B & 41.24 & 0.00 & 0.03 & 0.04 & 10.08 & 0.16 & 49.23 & 0.20 & 0.24 & 101.21 & 89.3 & & \\
\hline OLV 1 & B & 41.15 & 0.00 & 0.03 & 0.06 & 9.9 & 0.16 & 49.04 & 0.21 & 0.26 & 100.87 & 89.4 & & \\
\hline OLV 1 & B & & 0.00 & 0.03 & 0.07 & 9.6 & 0.20 & 49.40 & 0.21 & 0.25 & 101.00 & 89.7 & & \\
\hline Average & & 41.19 & 0.00 & 0.03 & 0.06 & 9.89 & 0.18 & 49.22 & 0.21 & 0.25 & 101.03 & 89.5 & & \\
\hline OLV 2 & C & 41.51 & 0.00 & 0.00 & 0.02 & 9.63 & 0.15 & 49.47 & 0.10 & 0.33 & 101.06 & 89.9 & & \\
\hline OLV 3 & D & 41.0 & 0.0 & 0.0 & 0.0 & 12. & 0 & 47.5 & 0 & 0. & 101. & 86. & & \\
\hline Ol & D & & 0. & 0. & 0.05 & 10.71 & 0.13 & 49. & 0. & 0 . & & 88 & & \\
\hline Average & & 41.34 & 0.00 & 0.03 & 0.05 & 11.45 & 0.18 & 48.58 & 0.25 & 0.19 & 102.06 & 87.9 & & \\
\hline $\mathrm{OLV}_{4}$ & E & 41.38 & 0.00 & 0.02 & 0.05 & 9.41 & 0.18 & 49.34 & 0.21 & 0.24 & 100.83 & 89.9 & & \\
\hline OLV 5 & $\mathrm{~F}$ & 41.09 & 0.00 & 0.04 & 0.07 & 10.87 & 0.12 & 48.55 & 0.23 & 0.22 & 101.18 & 88.5 & & \\
\hline OLV 6 & G & 40.76 & 0.00 & 0.04 & 0.05 & 11.73 & 0.18 & 47.68 & 0.27 & 0.18 & 100.89 & 87.4 & & \\
\hline Mineral & Grain & $\mathrm{SiO}_{2}$ & $\mathrm{TiO} 2$ & $\mathrm{Al}_{2} \mathrm{O}_{3}$ & $\mathrm{Cr}_{2} \mathrm{O}_{3}$ & FeOT & $\mathrm{MnO}$ & $\mathrm{MgO}$ & $\mathrm{CaO}$ & $\mathrm{NiO}$ & Total & Mg\# & Cr\# & \\
\hline \multicolumn{15}{|c|}{ Sample 135-839B-25R-1, $38-41 \mathrm{~cm}$, Unit 3: } \\
\hline SPINEL & $\mathrm{Z}$ & 0.06 & 0.42 & 11.06 & 54.95 & 20.06 & 0.27 & 13. & 0.0 & 0.14 & 100.84 & 55.2 & 76.9 & \\
\hline SPINEL & $\mathrm{Z}$ & 0.0 & 0.39 & 10.55 & 55.63 & 20.02 & 0.25 & 13. & 0.6 & 0.1 & 100.85 & 55.3 & 78.0 & \\
\hline Average & & 0.05 & 0.41 & 10.81 & 55.29 & 20.04 & 0.26 & 13.87 & 0.01 & 0.12 & 100.85 & 55.2 & 77.4 & \\
\hline
\end{tabular}

Notes: Mineral and grain labels are mnemonic identifiers keyed to the data base; mineral designators are specific to each sample (i.e., PLAG $=$ plagioclase, $\mathrm{CPYX}=$ clinopyroxene, $\mathrm{OPYX}=$ orthopyroxene, $\mathrm{OLV}=$ olivine, and $\mathrm{SPINEL}=$ spinel), whereas grain designators are global. An (anorthite), Ca, Mg, Fe, Fo (forsterite), Mg\#, and Cr\# are in molecular percent. 

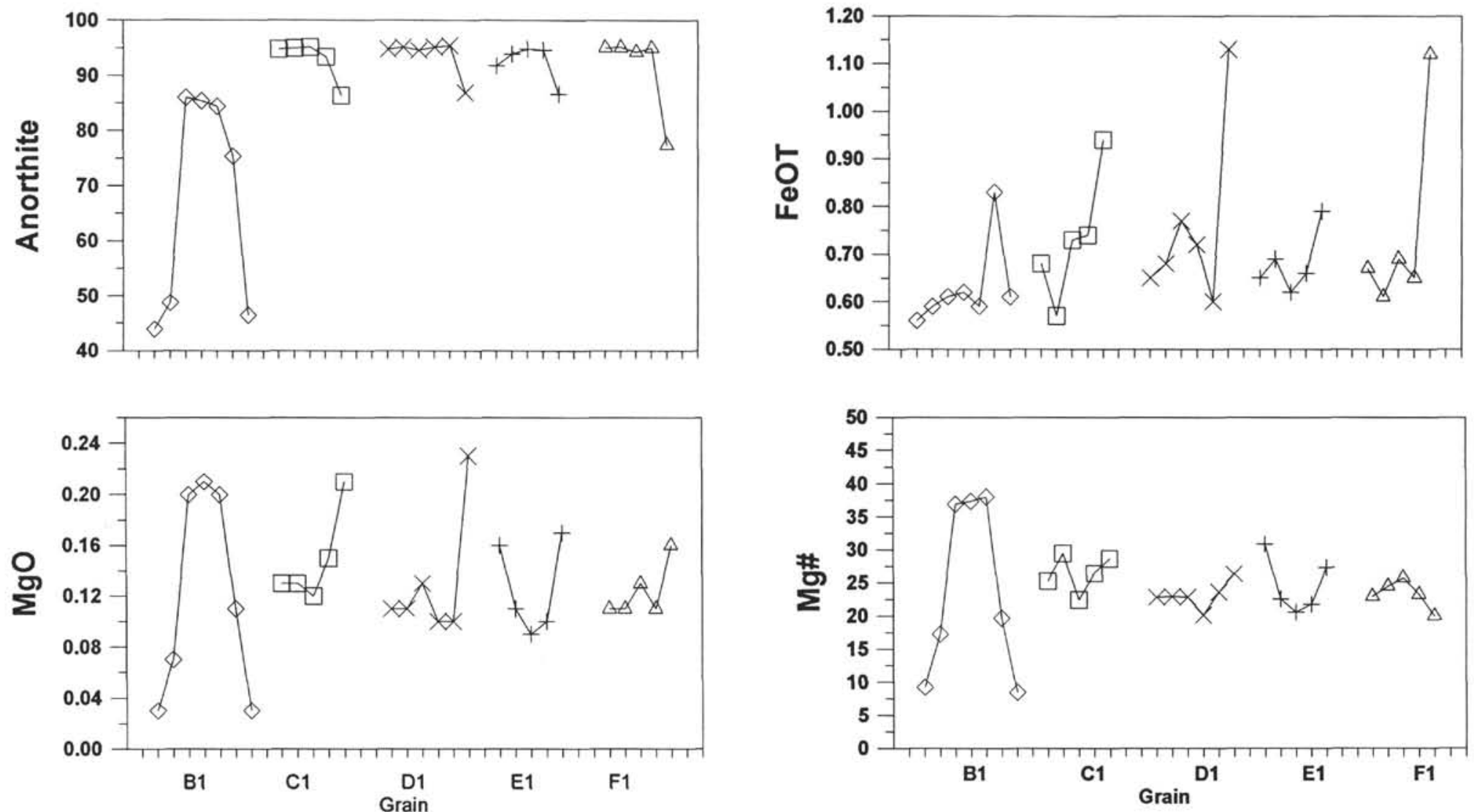

Figure 1. Comparison of plagioclase compositions in selected samples from Holes 836A (Grain B1); 839B, Unit 9 (Grains Cl and D1); and 839B, Unit 2 (Grains E1 and F1). Sequential profiles across grains are normalized to an arbitrary horizontal scale. Grain B1 is a sequential profile from rim to rim across a small microphenocryst; the others are core-to-rim profiles of phenocrysts. 

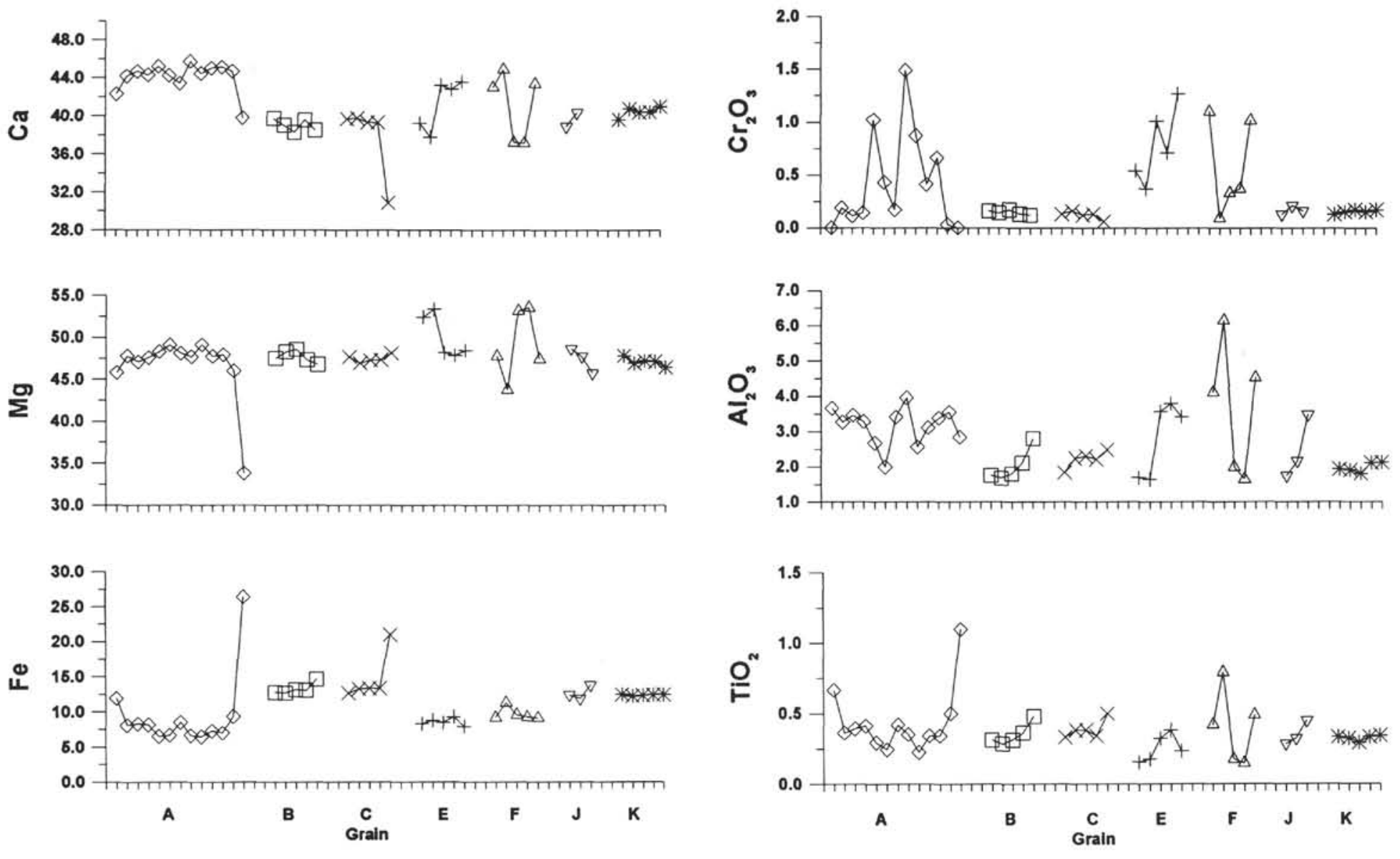

Figure 2. Comparative compositional variation in clinopyroxenes from Holes 836A (Grain A); 839B, Unit 2 (Grains B and D); $839 \mathrm{~B}$, Unit 3 (Grains E and F); and 839B, Unit 9 (Grains $\mathrm{J}$ and $\mathrm{K}$ ). Profiles are normalized to an arbitrary sequential scale as in Figure 1. Grain A is a rim-to-rim sequential profile across a sector-zoned crystal. The others are core-to-rim profiles in small grains, most of which are sector-zoned or show other optical variability. See text for further discussion. 

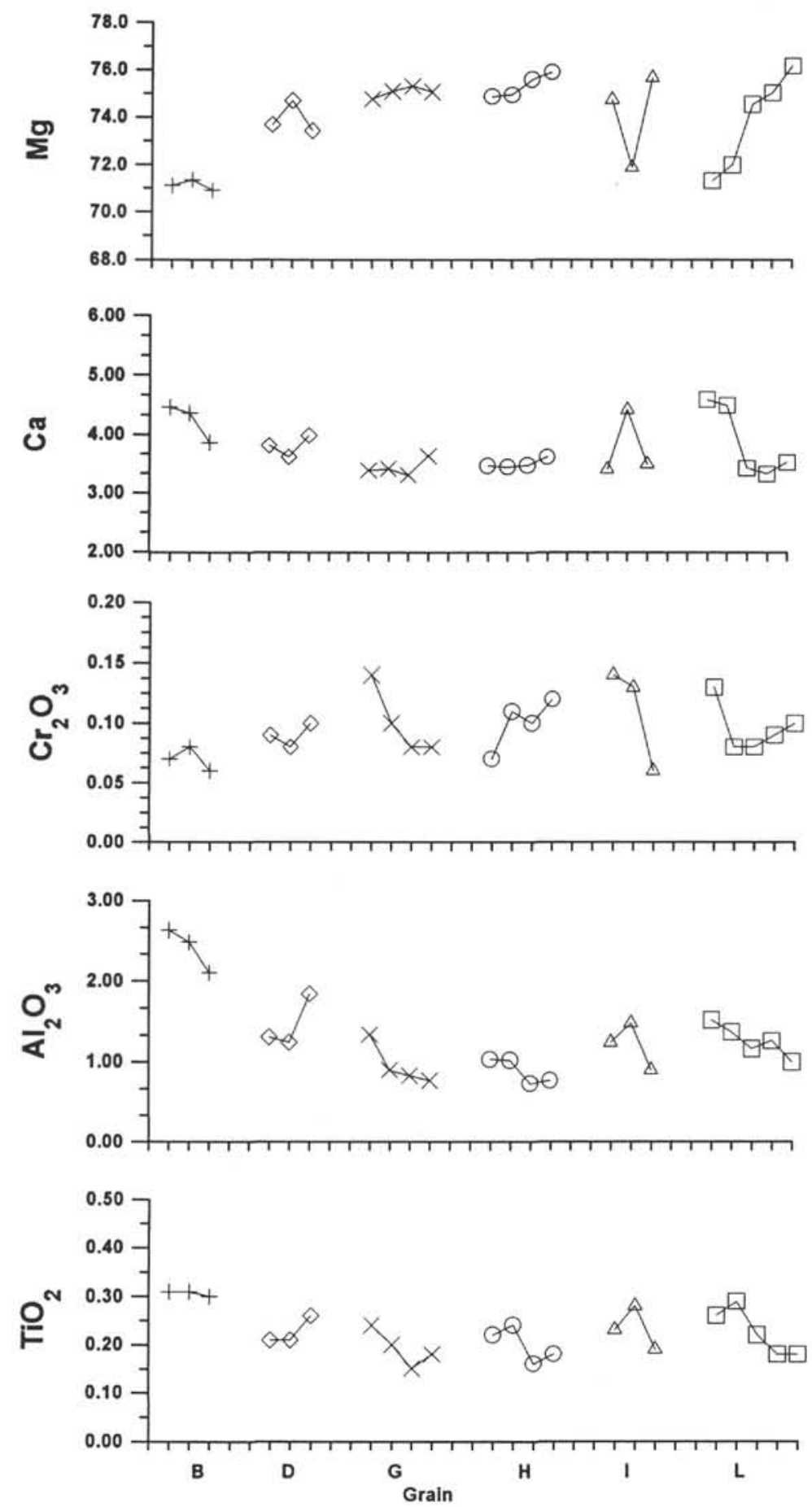

Figure 3. Comparison of compositional variation in orthopyroxenes from Hole 839B, Units 2 (Grains B and D) and 9 (Grains G, H, I, and L). These are small prismatic microphenocrysts showing little optical variability; probe points were chosen to show variability along or across each grain. See text for further discussion.

that group, a close correspondence exists between the plotted positions of glasses and bulk rocks, consistent with the aphyric nature of most of the samples. The exceptions are several moderately plagioclase-olivine phyric samples from Unit 7, which show the greatest offset from the glasses. Sites 835 and 836 (Fig. 5B) also show a trend that mimics the 1 -atm. phase boundary even more closely, consistent with the predominance of clinopyroxene-phyric samples at these sites.
The greatest departure from the projected phase boundary is shown by the olivine-rich samples from Hole 839B, Units 3 and 6 (Fig. 5C). These bulk-rock samples are distinctly offset toward the olivine apex, consistent with the high content of phenocrystic olivine observed in these samples in thin section. In CMAS, as in other popular graphic projections, these samples appear to lie on an olivine control line. The glasses from these units plot well away from the bulk 


\section{A}
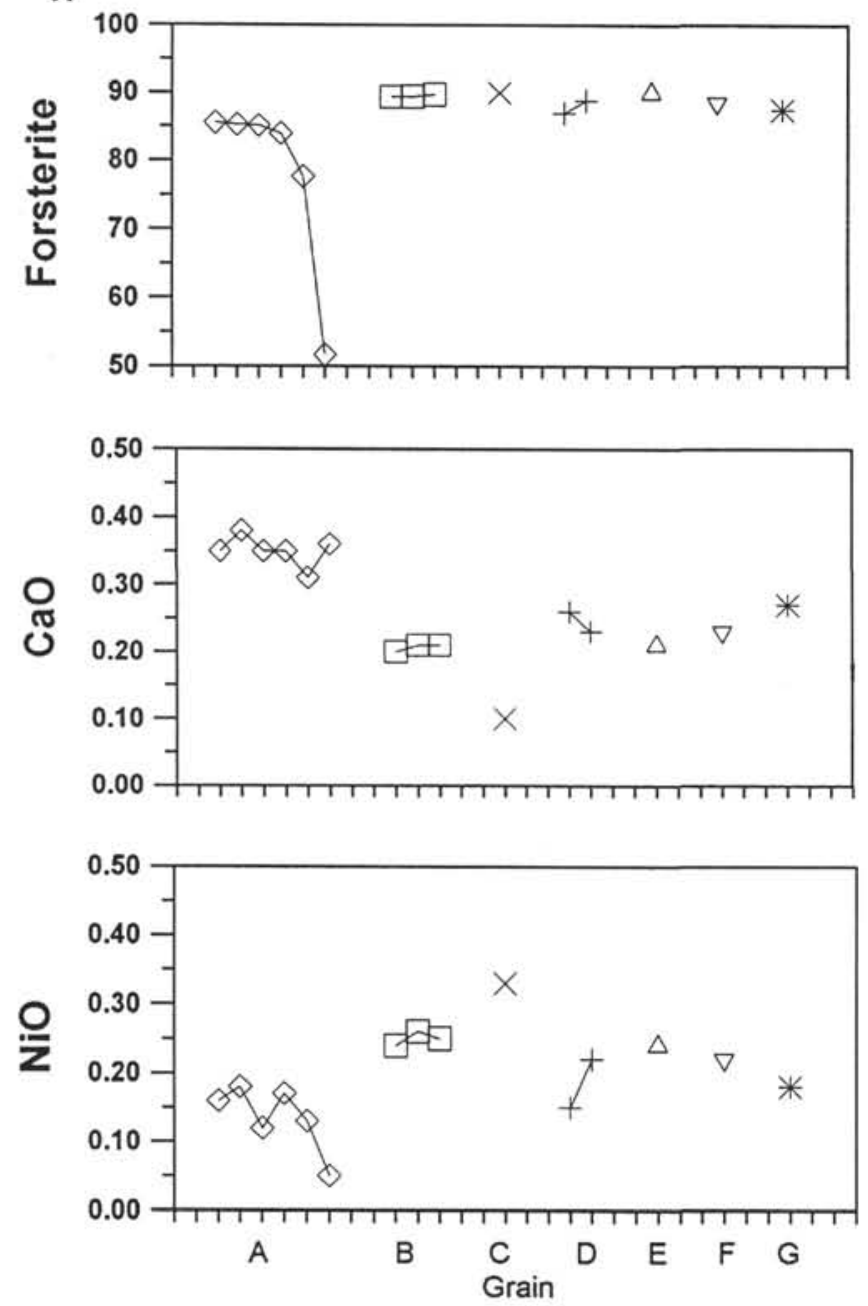
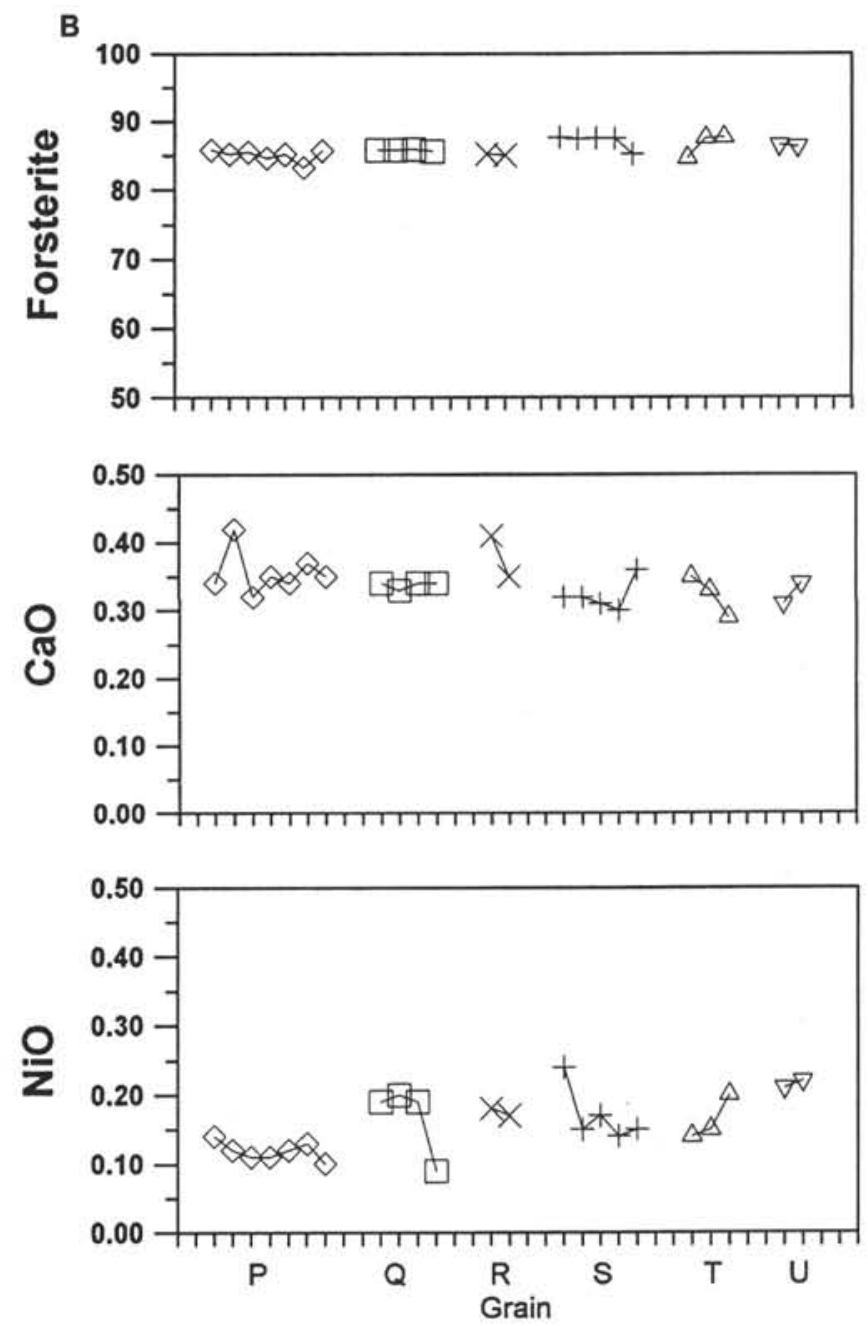

Figure 4. Compositional variation in olivines. A. Hole 836A, Unit 4 (Grain A); and Hole 839B, Unit 3 (Grains B-G). B. Hole 834B: Grains P-U are in sequence from top to bottom of Unit 7. Profiles are normalized to an arbitrary horizontal scale as in previous figures. See text for further discussion.

rocks and lie directly on the "dry" 1-atm. phase boundary, where they also are apparently close to saturation in low-Ca pyroxene. Bulk-rock compositions from Hole $839 \mathrm{~B}$, Unit 1 , form a cluster to the left of these glasses; this, along with the presence of clinopyroxene phenocrysts, suggests that Unit 1 melts have equilibrated either at higher dry pressure or have higher water contents. The remaining samples, mostly from Units 5, 7, and 9 in Hole 839B, but including several evolved samples from Site 836 , include orthopyroxene among their phenocrysts and appropriately plot beyond the olivine-orthopyroxene reaction point. Again, the offset to the left suggests equilibration at elevated pressure and/or water content, and is similar to the evolved glasses from Site 834 .

As another check on the correspondence between natural rock data and the experimental phase boundaries, we have plotted orthopyroxene-phyric samples from the modern Tonga Arc volcanoes in Figure 5D. These include dacites, which plot as they should, well up toward the silica apex. All but three points lie above the projected position of the olivine-orthopyroxene reaction point, consistent with their natural phase assemblages.

In the CMAS projection from silica (Fig. 6), some other aspects of the data are revealed. In general, samples on the multiply saturated phase boundary will plot as a tight cluster in this projection, since it is looking almost directly along the liquid line of descent. The data from Site 834 (Fig. 6A) show a suggestion of a "control line" pro- jected away from the central cluster toward the plagioclase apex; these are plagioclase-phyric samples which may contain cumulate phenocrysts or xenocrysts. The evolved glasses are again offset from the main group away from clinopyroxene; this projection shows that they also are shifted toward plagioclase, an effect consistent with equilibration at increased water content (Gaetani et al., this volume). All Site 834 data are offset in this direction relative to Sites 835 and 836 . Figure $6 \mathrm{~B}$ shows the plotted positions of the olivine-clinopyroxene phyric samples (mostly from Hole 839B) and the orthopyroxenephyric evolved samples from Site 836 and Hole $839 \mathrm{~B}$. The apparent Hole $839 \mathrm{~B}$ olivine control line is emphasized in this projection, which suggests that it even affects the bulk composition of Unit 1 samples just below and to the left of the cluster of glasses in the center of the diagram. This is the same cluster of glasses that lies at the 1-atm. dry, olivine-orthopyroxene reaction point in Figure 5C. This effectively locates the projection of that point in this diagram and places it within the cluster of data from Sites 835 and 836 . Figure $6 \mathrm{C}$ is included to show the details of the data for Sites 835 and 836 , and illustrates well the way the elongated array of points in Figure 5B is compressed to an ovoid cluster in this projection.

Data from the modern Tonga Arc are also plotted in Figure 6B; they display an apparent plagioclase control line, a feature not previously recognized, which to the best of our knowledge is not a consequence of strong plagioclase accumulation in these moderately to sparsely 

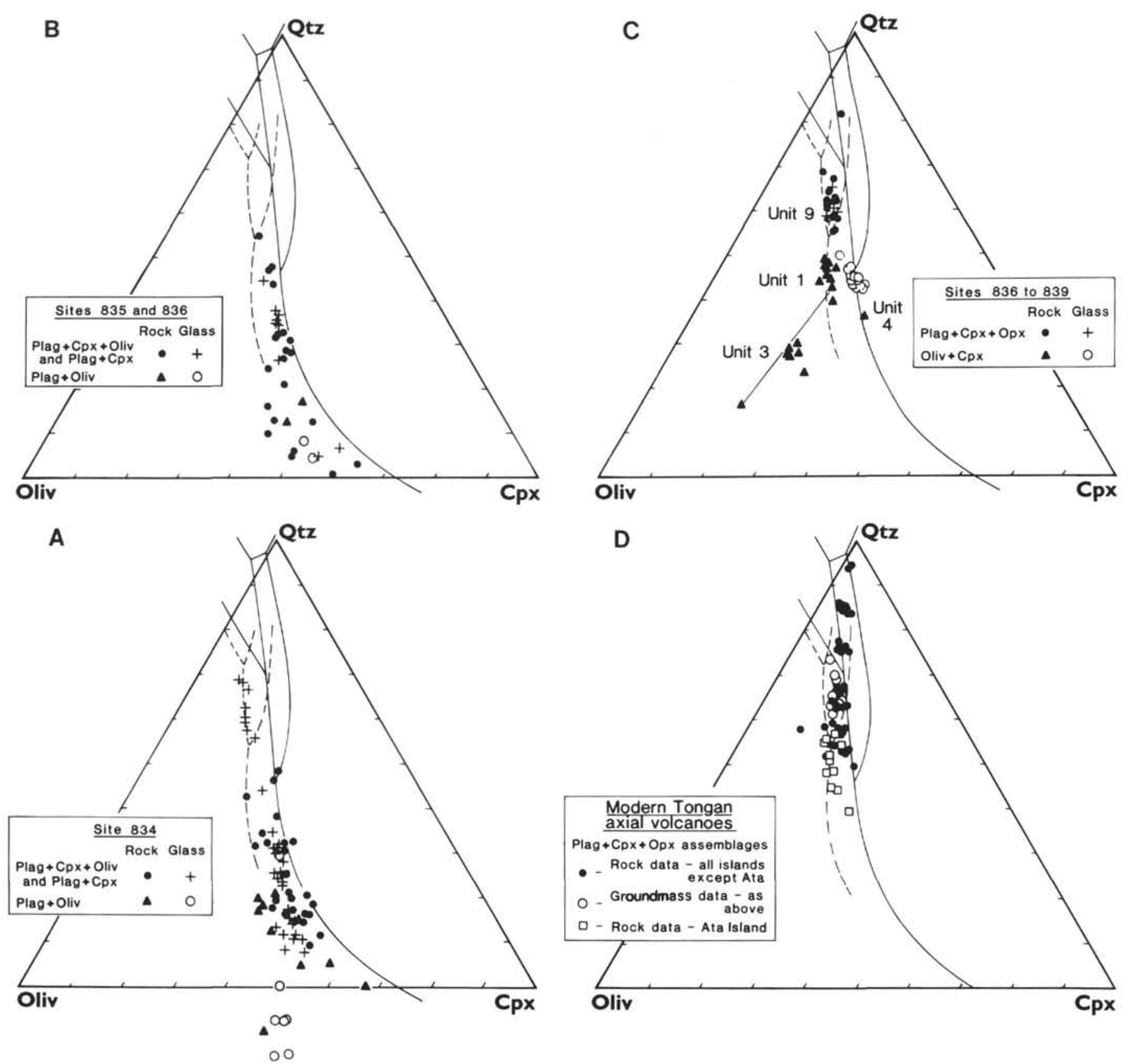

Figure 5. CMAS projection from plagioclase for glass and whole-rock data from all sites. Curved solid lines are the projected positions of the 1-atm. dry, multiply saturated phase boundaries, or cotectics, along which all liquid compositions will move in response to crystallization of olivine or orthopyroxene, clinopyroxene, and plagioclase. The dashed lines show schematically the expected direction of shift of these boundaries with increasing pressure; a specific pressure is not implied. Point coding distinguishes between rock and glass, and indicates the nature of the phase assemblages observed in thin section in these samples. Modern Tonga data are from Ewart et al. (1973). See text for further discussion.

phyric rocks. It does encompass most of the range of variation in the Lau Basin sites, with the exception of the olivine-enriched samples. This elongation lies in the general direction of the expected "trajectory" of the projected equilibrium liquid line of descent with increasing pressure and water saturation, and implies a possible role for these effects in the evolution of the island lavas.

\section{Covariances in Al\#-Fe\#}

Reid et al. (1989) showed that orthogonal plots of the Al-number vs. the $\mathrm{Fe}$-number produced the same data groupings and trends as the
CMAS projection from plagioclase; furthermore, this projection has the added advantage that analytical errors, especially for silica and soda, have less effect on the plotted positions of points. In these projections, olivine plots near the upper left corner of the diagram, and clinopyroxene plots toward the lower left corner. As in the CMAS projection from plagioclase, plagioclase saturation is assumed. This diagram therefore is very sensitive to variations in the relative proportions of olivine relative to clinopyroxene that may be crystallizing, and it has been useful in deducing phase relations in MORB. We have taken advantage of the relative simplicity of this diagram to illustrate in more detail the relation of data from Sites 834,836 , and 839 to the inferred 


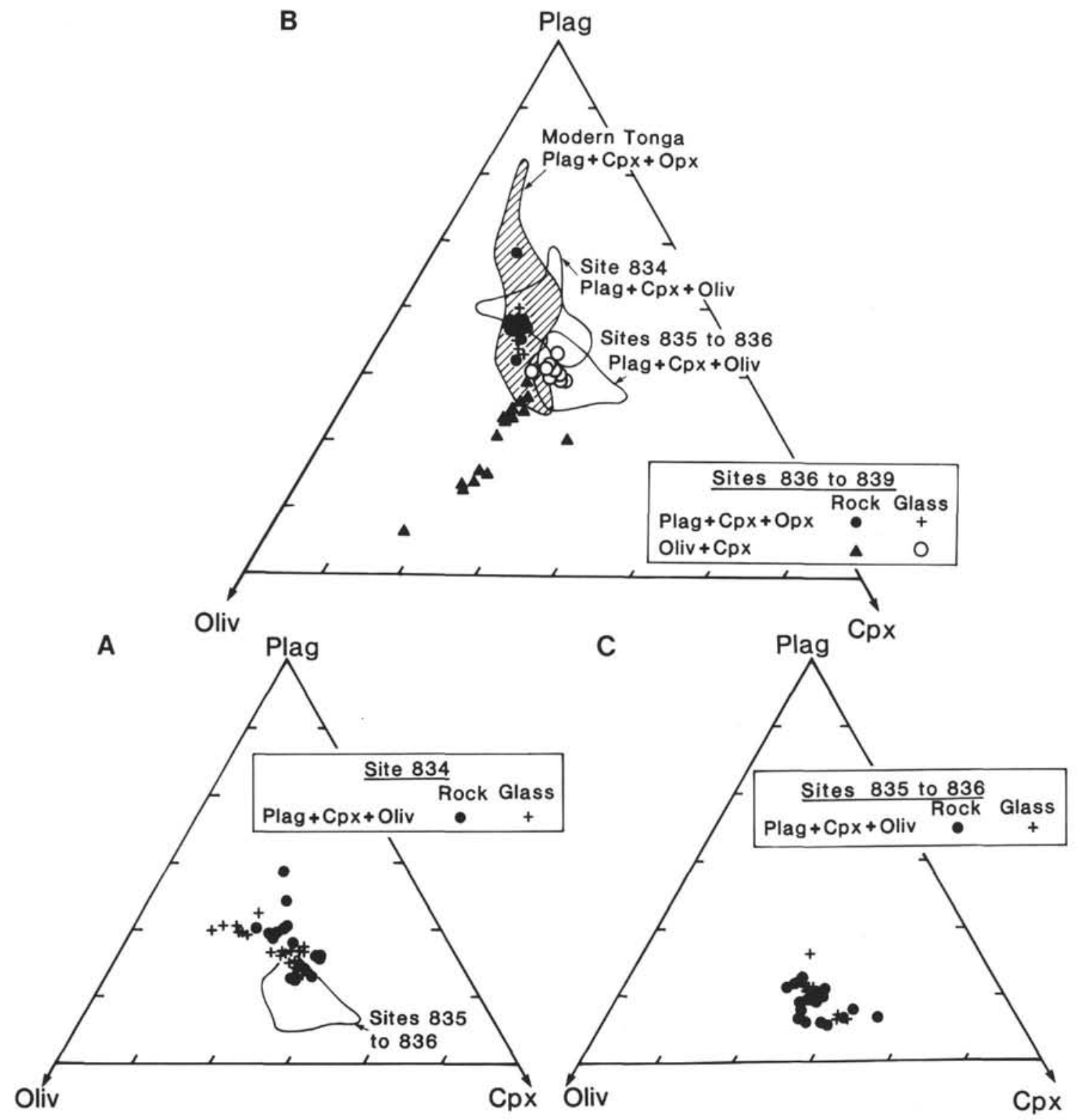

Figure 6. Projection from Qtz (silica) in the CMAS system for glass and whole-rock data from all sites. Point coding is used as in Figure 5 to distinguish glass, rock, and different phase assemblages. In this projection, the multiply saturated phase boundary plots essentially as a point and is not shown. See text for further discussion.

1-atm. phase boundary, and also to show the relative positions of glass vs. bulk-rock data and of individual lithologic units within the total data distributions. For each site, the upper diagram shows the data subdivided into glass and whole rock, and the trace of the 1-atm. dry cotectic boundary based on laboratory experiments on MORB. Limited experimental data at higher pressures (Grove et al., 1990) indicate that at 5-8 Kbar, the phase boundary (cotectic) moves up in this diagram by the amount of about $+0.1 \mathrm{Al \#}$ unit. This is analogous to, and consistent with, the shift away from clinopyroxene toward olivine in the CMAS projection.

Figure 7A shows the rock and glass groupings for Site 834 , with the corresponding classification into lithologic units in Figure 7B. For simplification, lithologic units with very similar compositions have been grouped together. The Unit 7 glass and bulk rocks plot as two distinct groups, with the glass offset from the rock toward the phase boundary, a relation consistent with a small amount of late-stage, low-pressure olivine (and plagioclase) crystallization. This stage may be represented by the narrow zones observed on Unit 7 phenocrysts, as discussed by Bryan and Pearce (this volume). There is a close approach to the cotectic among glasses and bulk rocks of more intermediate composition (Units 1, 2, 4, 5, 6, 8, 9, and 13). The andesitic Units 10 and 12 again are offset to the olivine side of the cotectic (cf. Fig. 5A).

The Site 836 data show a similar but simpler pattern (Figs. $8 \mathrm{~A}$ and $8 B$ ). Units 3 and 4 and Subunits $4 \mathrm{~A}$ and $4 \mathrm{~B}$ appear to follow a trend dominated by olivine; the few glasses available for these units all plot in a slightly more evolved position almost on the cotectic and a little to the right of the bulk-rock data, suggesting that they are already affected by a small amount of clinopyroxene crystallization. For the most evolved, andesitic samples, a close correspondence exists between the glass and bulk-rock data, and again a small offset of these compositions into the olivine field is present.

The olivine control line is clearly displayed in the data for Site 839 (Fig. 9). The Unit 1 bulk-rock data appear to be colinear with the Unit 3 
A

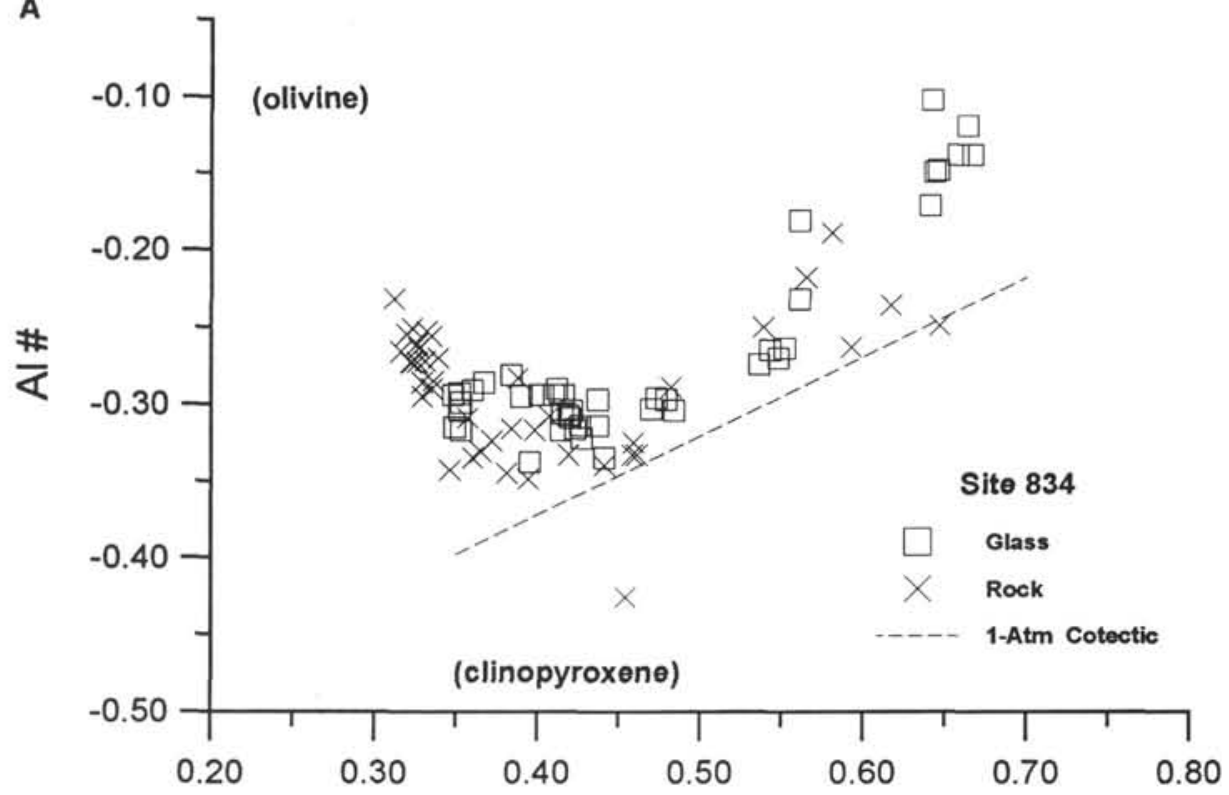

B

$\mathrm{Fe} \#$

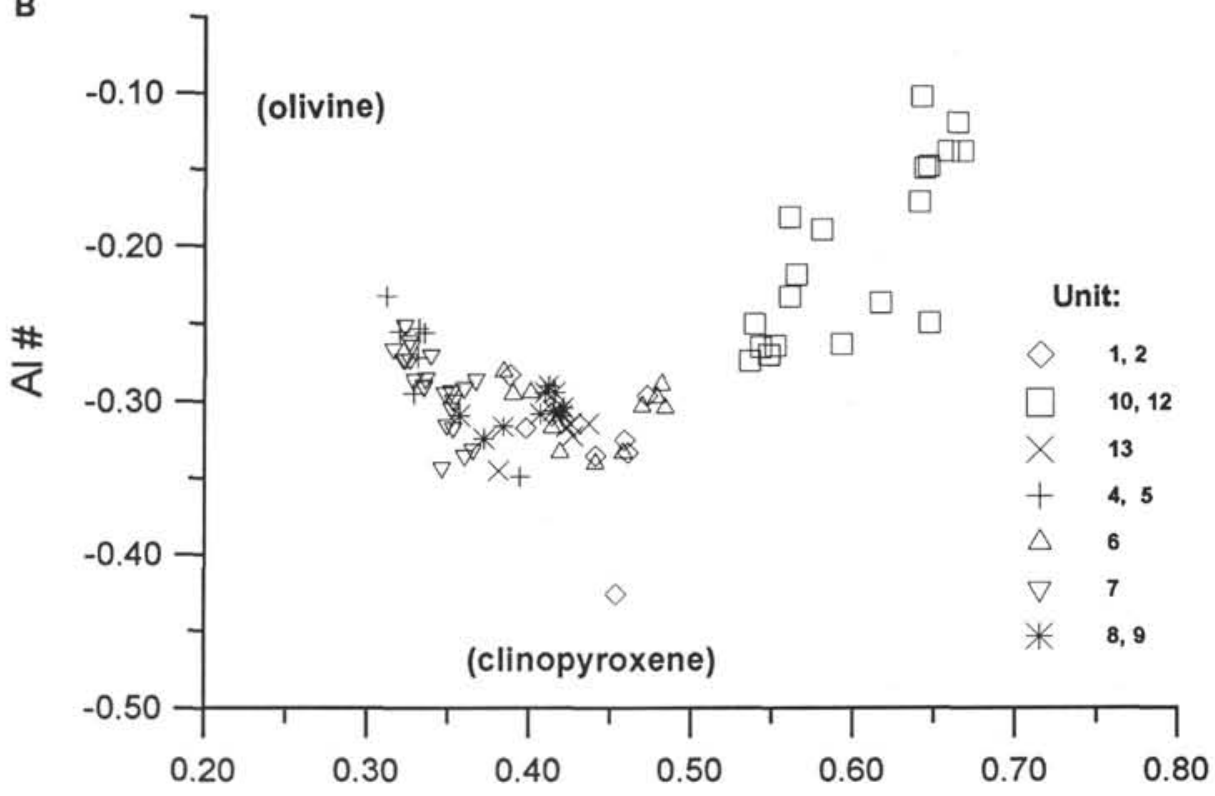

$\mathrm{Fe} \#$

Figure 7. Al-Fe plots for all glass and whole-rock data from Site 834, computed according to method of Reid et al. (1989). A. Data coded to distinguish bulk rock and glass data; diamonds show trace of the 1-atm. dry olivine-pyroxene phase boundary. The olivine field is above, and clinopyroxene field is below, this boundary, B. Data coded to distinguish major lithologic units. Units of similar composition have been grouped together for clarity.

glass and Unit 3 bulk-rock data; a possible interpretation is that Unit 1 has been partitioned into these two units by olivine and clinopyroxene crystallization, with subsequent physical separation of a portion of this magma into liquid (glass) and cumulate (bulk-rock) components. The orthopyroxene-phyric andesites (Units 2, 5, 7, and 9) plot similarly to the andesitic rocks from Site 834. Except for the Unit 3 glass, none of the data lie close to the 1-atm. phase boundary. As noted in the discussion of the CMAS projection, this, and the presence of clinopyroxene phenocrysts in Unit 1 , suggests a higher pressure paragenesis for all samples from Site 839 .

\section{Pearce Plots}

Renewed interest has occurred in the use of Pearce plots for exploratory interpretation of crystal melt equilibria, largely because of the resolution of some concerns about their statistical validity (Pearce, 1987), and the promotion of the method by Stanley and Russell (1989a, 1989b) who have provided a relatively simple software package to facilitate creation of the plots. The method assumes that the data in question are derived from a common magma batch and are related by crystallization of specific crystals, assumptions 


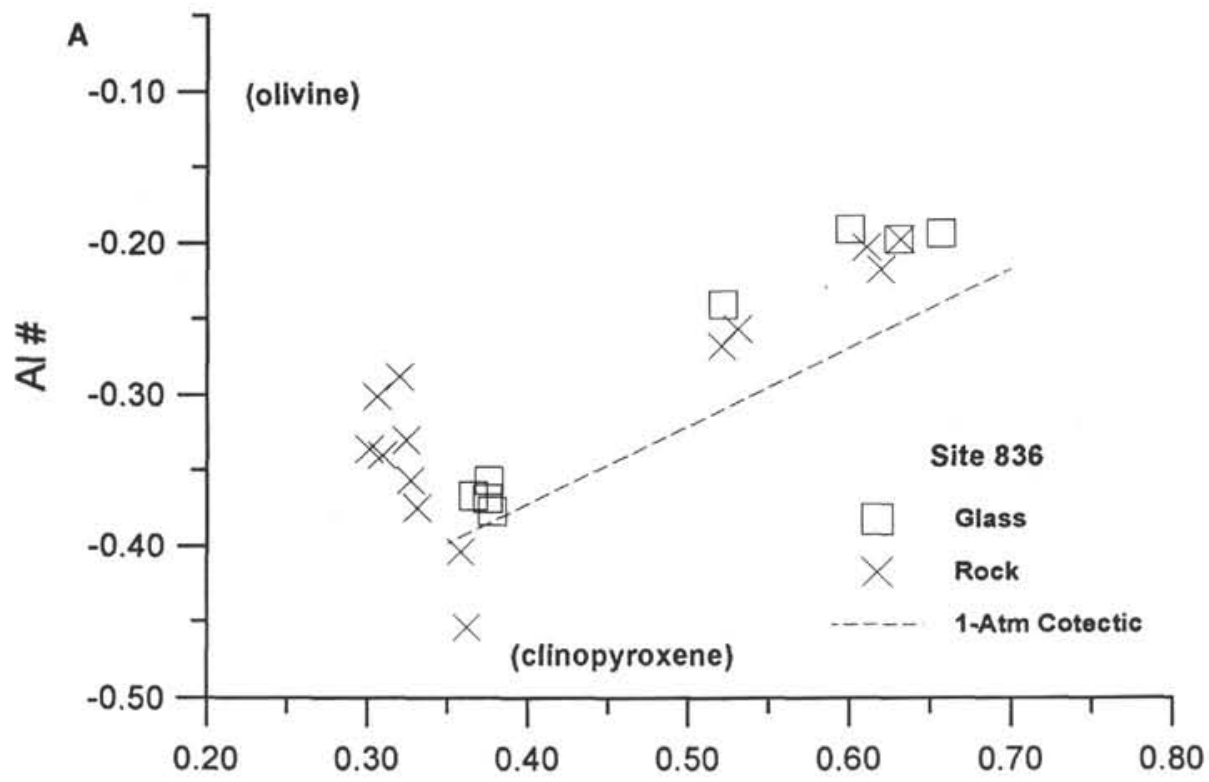

$\mathrm{Fe} \#$

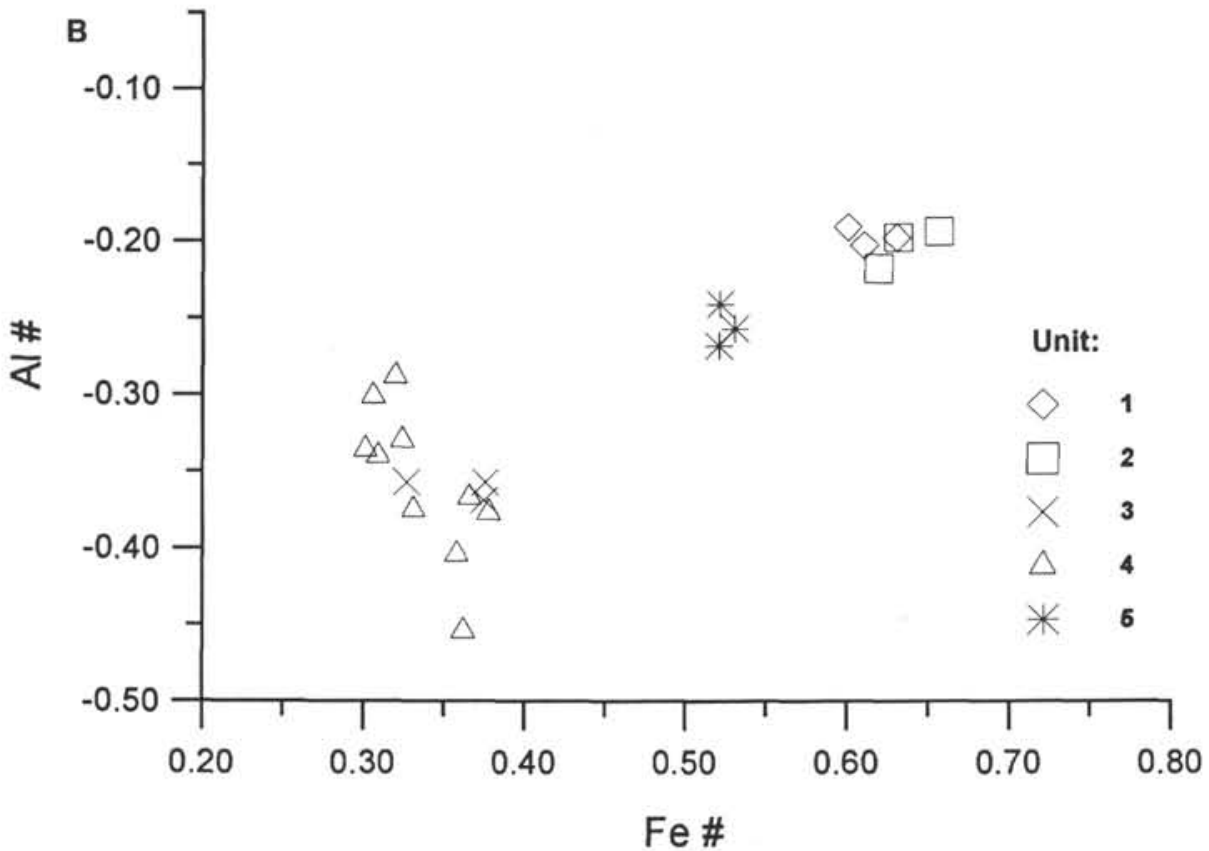

Figure 8. Al-Fe plots for all glass and whole-rock data from Site 836, with data coded as in Figure 7.

common to the other plots as well. A choice of variables is possible, depending on the mineral vectors one wishes to test.

For this study, we have chosen an ordinate that is sensitive to olivine and to a Ca-bearing phase, either clinopyroxene or calcic plagioclase. The abscissa responds very differently to clinopyroxene or plagioclase, however; as a result, crystallization only of mafic phases moves compositions down and to the left, whereas crystallization of plagioclase will move compositions down and to the right. Thus, this diagram is complementary to the $\mathrm{Al}-\mathrm{Fe}$ projection and to the CMAS projection from plagioclase. In the plots, we have shown only the bulk-rock data, and units are not point coded; however, the approximate "centers of gravity" of the major units are indicated by labels for Sites 834 (Fig. 10A) and 839 (Fig. 10C).

These plots show more clearly than those presented earlier that substantial differences may be present in the role of plagioclase in fractionation between the different sites, and between specific units within sites. There is a suggestion in the Site 834 data of possibly two different groups, each following parallel paths dominated by plagioclase fractionation to yield the evolved Units 10 and 12. At Site 836 (Fig. 10B), a similar paragenesis is implied. Perhaps most striking is the suggestion for Site 839 of mafic-dominated fractionation, with plagioclase playing only a minor role even in the evolution of the most evolved magmas. In the combined plot (Fig. 10D), the distinct differences both in the probable parental magmas and in their inferred liquid lines of descent are also clearly evident.

\section{MATERIALS BALANCE CALCULATIONS}

Chemical differences between inferred parental and residual magmas, or the chemical compositions of inferred mixes of any combi- 

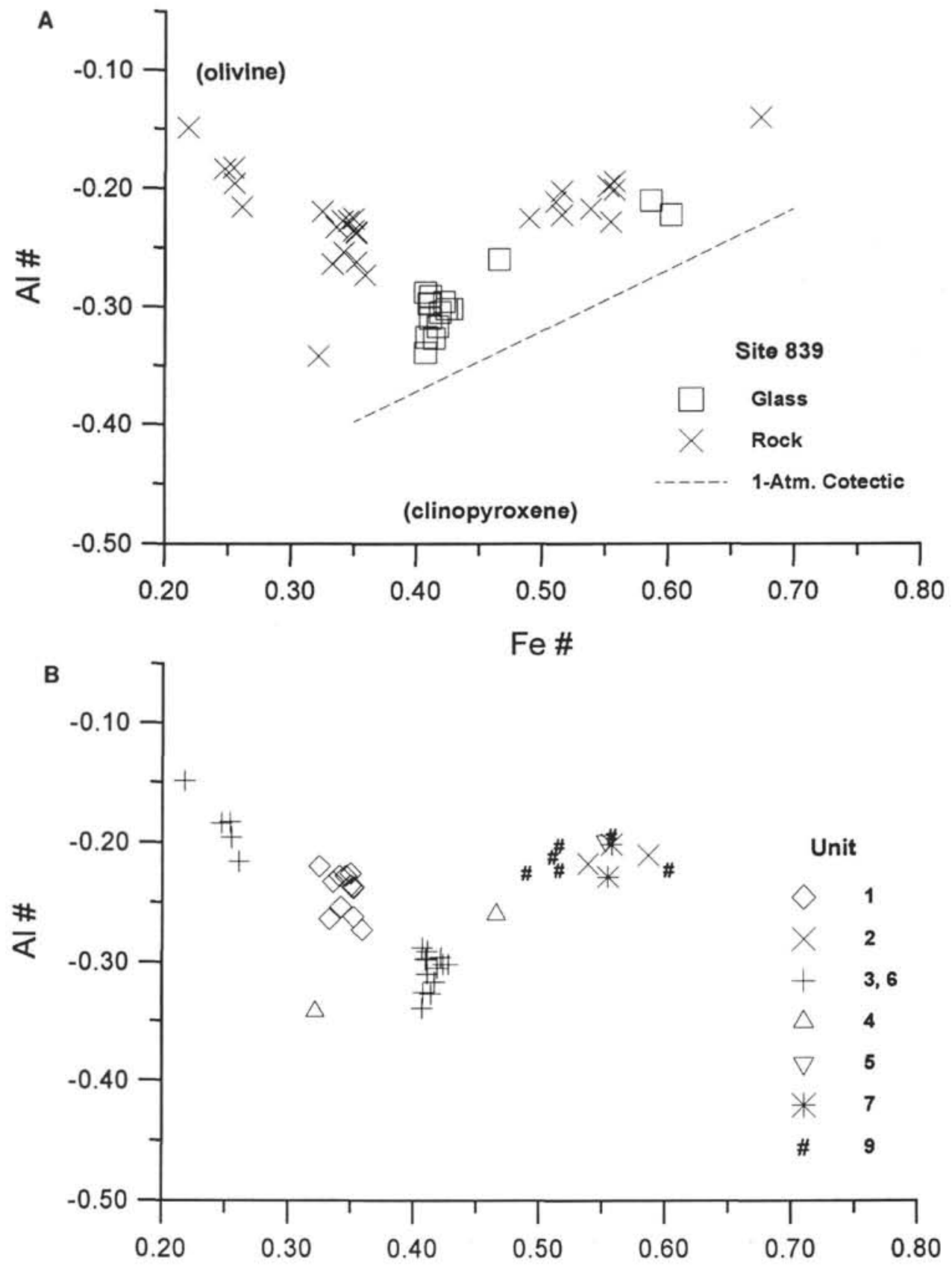

$\mathrm{Fe} \#$

Figure 9. Al-Fe plots for all glass and rock data from Site 839, with data coded as in Figure 7.

nation of crystals and liquids, can be quantitatively tested using materials balance calculations, which compare the best calculated combination of real liquid and crystal compositions to the observed composition of the supposed parent or mixed magma (Bryan, 1986). We have tested several such relations suggested by the graphic plots discussed above. Acceptable solutions, in which the calculated and observed compositions all are well matched, will have sums of squared residuals generally $<0.10$. For the relations tested here, most sums of squares are $<0.05$ and many are $<0.02$. These latter misfits approach those expected from internal binary rounding errors alone, and they are among the best we have ever obtained for such calculations. Thus, they are entirely consistent with the indications of the graphic plots, and their credibility must be judged on more subjective conceptual criteria, such as their consistency with trace element data and indications from laboratory crystallization experiments.

At Site 839, the bulk composition of Unit 3 rocks appears to be a consequence of the accumulation of observed mafic phenocryst phases of olivine, clinopyroxene, and spinel. The near colinearity of Unit 3 rocks, Unit 1 rocks, and Unit 3 glass suggests that either of the latter two could represent the liquid component of the mix. Because of obvious variations in individual rock samples within Unit 3, we have selected three individual samples to test as possible mixes of liquid and crystals. Mixes calculated using the average of the Unit 1 bulk rocks and the average of the Unit 3 glasses yield excellent fits for most elements, with the notable exception of $\mathrm{Na}_{2} \mathrm{O}$ and $\mathrm{K}_{2} \mathrm{O}$, which do not show the extent of "dilution" that would be expected from the amount 
A

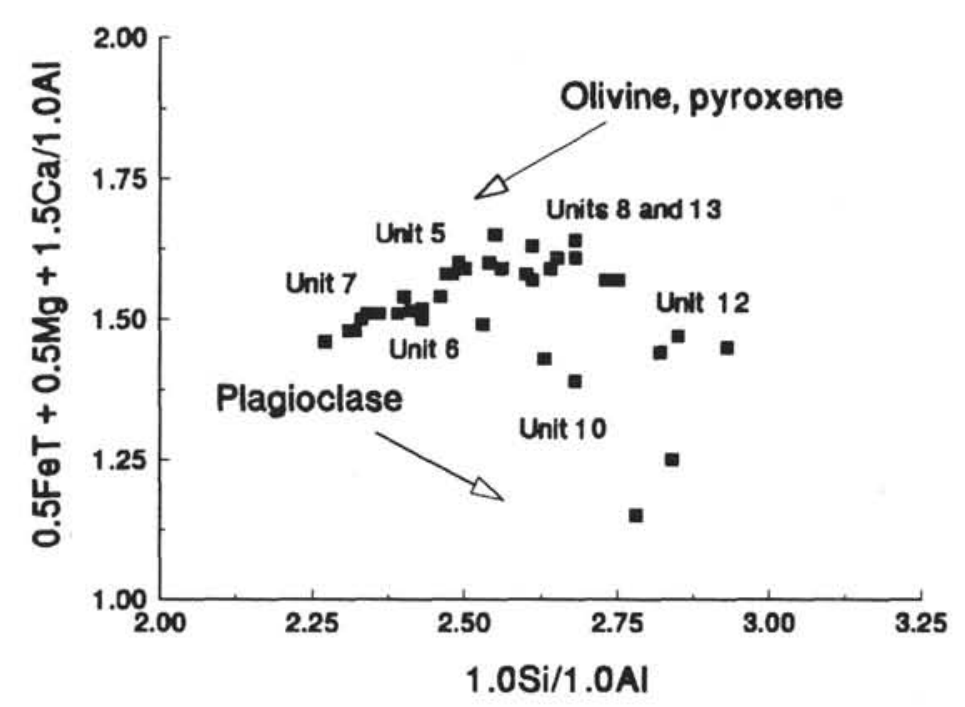

C

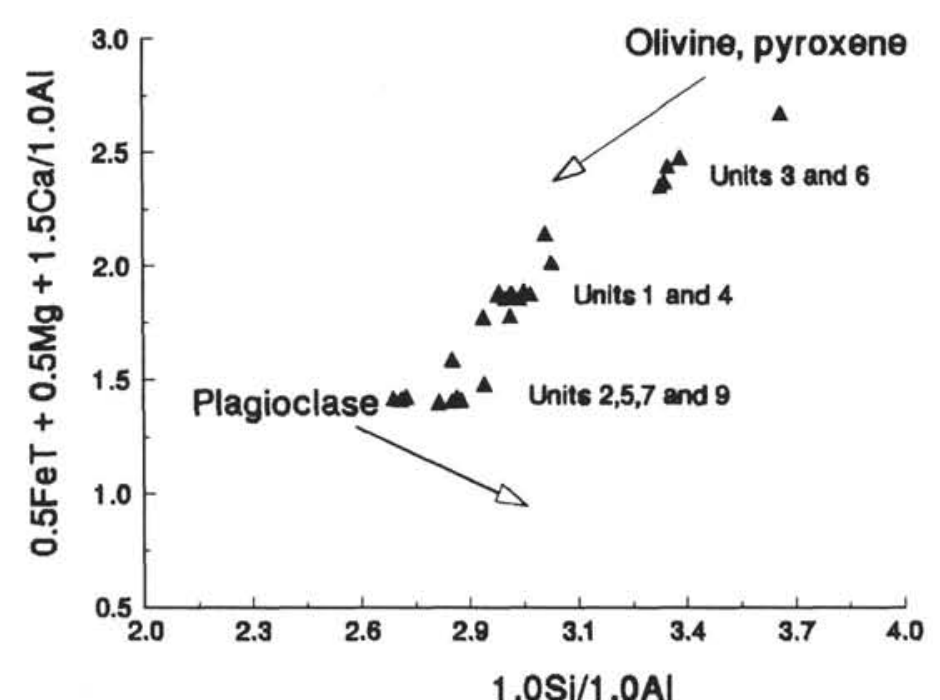

B

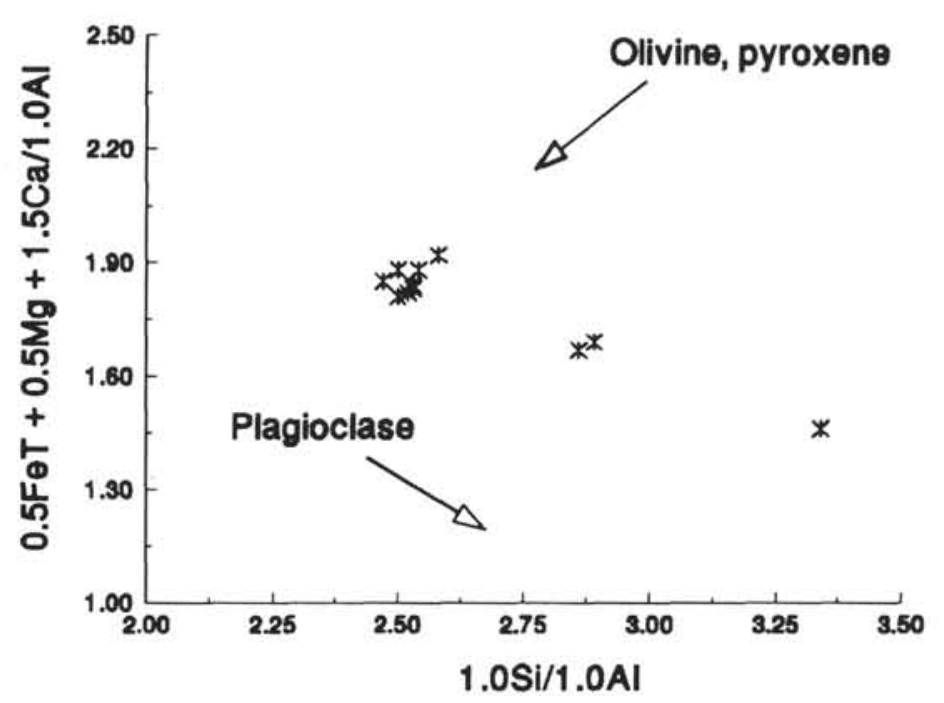

D

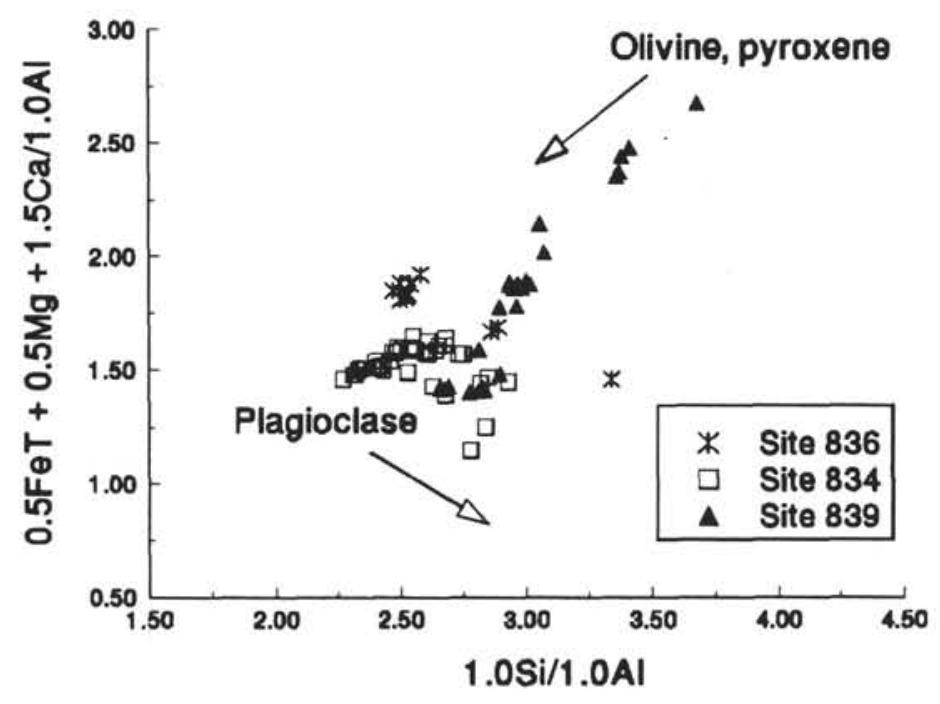


of alkali-free mafic phases required to satisfy the other elements. This problem extends to the trace elements, which as noted in the original shipboard studies, also do not change as would be expected. In all three of the Unit 3 bulk rocks, $\mathrm{Zr}$ and $\mathrm{Y}$ are almost invariant and are higher in concentration by several parts per million (ppm) than in the Unit 1 bulk-rock average, which should have been diluted by the addition of mafic phases with very low concentrations of these elements. Only a little comfort can be taken from the fact that $\mathrm{Ni}$ does show the greatest increase in Sample 135-839B-24R-1, which requires the largest amount of olivine. But this sample also has the highest concentration of $\mathrm{Cr}$, although it is Sample 135-839B-20R-1 that appears to have had the highest concentration of spinel and clinopyroxene added. Solutions using the Unit 3 glass as the liquid end member fare better (Table 4), as the higher alkali contents in the glass result in better overall fits.

The Unit 1 bulk-rock can be modeled as another member of the cumulate sequence, with the average Unit 3 glass again as the liquid end member. The fits in an initial calculation were excellent, with the exception of $\mathrm{Na}_{2} \mathrm{O}$, so the calculation was repeated, but with $\mathrm{Na}_{2} \mathrm{O}$ in the glass reduced to 1.50 from 1.90. The result of this calculation is given in Table 5, which shows that the fits are excellent for all elements including soda, as indicated by the very low sum of squares of residuals (Sum $R^{2}$ ). We cannot pursue this matter further without definitive trace element data for the Unit 3 glass. As we have shown, most of the major element data do support the idea that Units 3 and 1 all are part of a common cumulate series, but alkalis and some of the key trace elements fail to conform neatly to this simple relationship.

The andesitic lavas at Site 839 all can be related to the average Unit 1 bulk-rock as parent, using observed phenocrysts from a Unit 9 sample. All solutions yield fits with sums of squares 0.02 or less (Table 6). As implied in the Pearce plots, plagioclase plays a subordinate role, making up less than half the crystal phase assemblage. All require somewhat less than $50 \%$ crystallization, and the enrichment of $\mathrm{Y}, \mathrm{Zr}$, and $\mathrm{Ce}$ in the andesites relative to Unit 1 is that expected for elements with very small partition coefficients. The observed depletion in $\mathrm{Ni}$ can be accomplished with bulk partition coefficients of 3-4 for the combined clino- and orthopyroxene assemblage, numbers which are reasonable. The $\mathrm{Cr}$ depletion can easily be achieved with a clinopyroxene partition coefficient of about 6 , also well within the accepted range of values observed, for example, for the chemically similar modern Tonga Arc lavas (Ewart et al., 1973). The clinopyroxene is relatively calcic, as is the plagioclase, and spinel is a small but essential part of the crystal assemblage, characteristics that are consistent with crystallization at relatively high water content and 1.5-2.0 Kbar pressure (Gaetani et al., this volume). However, the experiments also showed that orthopyroxene crystallization is delayed under these conditions, although it is expected to replace olivine as crystallization continues. The experiments did not go beyond $35 \%$ crystallization. It is very likely that "olivine out" occurs at about $40 \%$ crystallization, and that the assemblage we observe in these rocks reequilibrated to an orthopyroxene-bearing assemblage. This is consistent with the $\mathrm{FeO}$ and $\mathrm{MgO}$ behavior in plagioclase, as discussed earlier. Olivine rimmed by orthopyroxene does appear in a thin section of one of the Unit 1 rocks (Gaetani et al., this volume). Another possibility is that "olivine out" was triggered by loss of water as the magma approached
Table 4. Best-fit estimates of three Hole 834B Unit 3 bulk rocks.

\begin{tabular}{cccccc}
\hline & \multicolumn{5}{c}{ Calculated weight fractions } \\
\cline { 2 - 6 } Fit to & Glass & Olivine & Clinopyroxene & Spinel & Sum $R^{2}$ \\
\hline 135-834B- & & & & & \\
24R-1 & 0.6972 & 0.2374 & 0.0607 & 0.0092 & 0.0075 \\
20R-1 & 0.7298 & 0.1625 & 0.0985 & 0.0365 & 0.0703 \\
19R-1 & 0.7644 & 0.1468 & 0.0845 & 0.0184 & 0.0519 \\
\hline
\end{tabular}

Notes: Data represents mix of Unit 3 glass and minerals. Sum $R^{2}=$ sum of squared residuals for major element oxides.

Table 5. Best-fit estimates of Hole 839B Unit 1 bulk-rock average as a mix of Unit 3 glass and minerals.

\begin{tabular}{lccccc}
\hline & \multicolumn{5}{c}{ Calculated weight fractions } \\
\cline { 2 - 6 } Fit to & Glass & Olivine & Clinopyroxene & Spinel & Sum $R^{2}$ \\
\hline Unit 1 & 0.9423 & 0.0531 & 0.0184 & 0.0000 & 0.0146 \\
\hline
\end{tabular}

Note: $\mathrm{Glass} \mathrm{Na}_{2} \mathrm{O}$ has been reduced as described in the text.

eruption at the seafloor. For further discussion of andesite fractionation at Site 839, see Gaetani et al. (this volume).

Fractionation follows very different paths at Sites 834 and 836 . As suggested by the graphic constructions, at Site 834 plagioclase constitutes half or more of the crystallizing assemblage required to yield the Unit 10 and 12 andesitic rocks from Unit 5, which was selected as the bulk-rock parent (Table 7). The best plagioclase composition for these solutions is about $\mathrm{An}_{85}$, although the clinopyroxene is still very calcic. The depletion in $\mathrm{Al}_{2} \mathrm{O}_{3}$ and enrichment in iron and silica are characteristics of fractionation at low pressure, dry (Gaetani et al., this volume). Unit 5 appears to be an equally good choice of parent for both Units 10 and 12, so the difference in fractionation paths in the Pearce plots may reflect the significantly higher proportion of plagioclase required in the Unit 12 solution. Some caution is suggested by trace element enrichments; although Unit 12 is more evolved than Unit 10 , it is not proportionately more enriched in $\mathrm{Y}, \mathrm{Zr}$, and $\mathrm{Ce}$. More analyses of the Site 834 phase assemblages may help to clarify the details of these fractionation paths and the associated differences in trace element enrichments.

Andesites at Site 836 can be derived from Subunit $4 \mathrm{~A}$ using the same phase assemblage, except magnetite yields better solutions than spinel (Table 8). Small magnetite octahedra are present in many of these rocks, but none were suitable for analysis in the Unit 4 rock selected for study. A magnetite from Late Island in the Tonga Arc (Ewart et al., 1973) was used in the calculation. Although the major element fits are acceptable, the nearly fourfold increase in incompatible trace elements implied by the high degree of crystallization was not observed in the andesites of Units 1, 2, and 5. Clearly, this relationship also requires further study.

\section{CONCLUSIONS}

The liquid lines of descent suggested by a variety of graphic plots of Leg 135 lavas, the compositions and combinations of coexisting

Table 6. Best-fit estimates of Hole 839B Unit 1 andesites.

\begin{tabular}{ccccccc}
\hline & \multicolumn{5}{c}{ Calculated weight fractions } \\
\cline { 2 - 7 } Fit using & Residual & Clinopyroxene & Orthopyroxene & Plagioclase & Spinel & Sum $R^{2}$ \\
\hline Unit 2 & 0.5319 & 0.1484 & 0.1368 & 0.1753 & 0.0191 & 0.0143 \\
Unit 5 & 0.5377 & 0.1607 & 0.1354 & 0.1651 & 0.0169 & 0.0175 \\
Unit 7 & 0.5186 & 0.1607 & 0.1387 & 0.1761 & 0.0186 & 0.0204 \\
Unit 9 & 0.5799 & 0.1414 & 0.1329 & 0.1443 & 0.0097 & 0.0093 \\
\hline
\end{tabular}

Notes: Data represents Hole 839B Unit I bulk-rock averages as parent, using silicate phases from Unit 9 andesite, Unit 3 spinel, and Units 2,5, 7, and 9 bulk-rock averages. 
Table 7. Best-fit estimates of Hole 834B Unit 5 andesites.

\begin{tabular}{llccccc}
\hline & \multicolumn{5}{c}{ Calculated weight fractions } \\
\cline { 2 - 7 } Fit using & Residual & Clinopyroxene & Plagioclase & Olivine & Spinel & Sum $R^{2}$ \\
\hline Unit 10 & 0.4877 & 0.1769 & 0.2311 & 0.0805 & 0.0325 & 0.0325 \\
Unit 12 & 0.4283 & 0.1423 & 0.3193 & 0.1119 & 0.0000 & 0.0281
\end{tabular}

Notes: Data represents Hole 834B Unit 5 bulk-rock averages as parent silicate phases from Hole 836A Unit 4 and spinel from Hole 834B Unit 7.

Table 8. Best-fit estimates of Hole 836A Subunit $4 \mathrm{~A}$ andesites.

\begin{tabular}{lllllll}
\hline & \multicolumn{5}{c}{ Calculated weight fractions } \\
\cline { 2 - 7 } Fit using & Residual & Clinopyroxene & Plagioclase & Olivine & Magnetite & Sum $R^{2}$ \\
\hline Unit 1 & 0.1942 & 0.3157 & 0.3954 & 0.0465 & 0.0360 & 0.0145 \\
Unit 2 & 0.1775 & 0.3190 & 0.4041 & 0.0482 & 0.0392 & 0.0201 \\
Unit 5 & 0.2824 & 0.2836 & 0.3526 & 0.0425 & 0.0294 & 0.0165 \\
\hline
\end{tabular}

Notes: Data represents Hole $836 \mathrm{~A}$ Subunit $4 \mathrm{~A}$ bulk-rock averages as parent silicate phases from Hole 836A Unit 4 and magnetite from Late Island andesite, Tonga.

natural mineral phases in selected rock samples, and the materials balance calculations based on these data, all support the derivation of chemical variation in these rocks by crystal-melt fractionation at variable pressures. However, the very calcic plagioclase observed in some of these rocks also requires substantial amounts of water; plagioclase in dry melts tends to become more sodic with increasing pressure, not more calcic. This certainly is consistent with the high vesicularity of most of these rocks. The highest water contents are required to explain the variations in the Hole $839 \mathrm{~B}$ rocks, which are mineralogically and chemically very similar to the glass and mineral components produced by experimental crystallization of a Hole 839B, Unit 1, rock (Gaetani et al., this volume). Fractionation in the Hole 834B and 836A rocks is generally more "MORB-like," although relatively calcic plagioclase again indicates at least moderate pressure and water contents. In these calculations, some problems remain with misfits in trace elements. The apparently simple cumulate trend suggested by petrography and the graphic projections in Hole 839B also are not satisfactorily resolved by the new data, as substantial misfits are still present for both compatible and incompatible trace elements. Minor element heterogeneity in clinopyroxenes in Unit 3 indicates that Unit 3 may not be a simple cumulate but a partly assimilated, preexisting cumulate that may have had a different trace element signature than the assimilating magma.

\section{ACKNOWLEDGMENTS}

We thank M. Sulanowska for sample preparation and XRF analyses, Glenn Gaetani for assistance with the microprobe analyses, and Kristin Nilsson for glass data used in some of our graphic presentations and calculations. This work was supported by the National Sci- ence Foundation through the Ocean Drilling Program, and through a grant from USSAC.

\section{REFERENCES}

Bryan, W.B., 1974. Fe-Mg relationships in sector-zoned submarine basalt plagioclase. Earth Planet. Sci. Lett., 24:157-165.

- 1986. Linked evolutionary data arrays: a logical structure for petrologic modeling of multisource, multiprocess magmatic systems. $J$. Geophys. Res., 91:5881-5900.

Bryan, W.B., Thompson, G., and Ludden, J.N., 1981. Compositional variation in normal MORB from $22^{\circ}-25^{\circ} \mathrm{N}$ : Mid-Atlantic Ridge and Kane Fracture Zone. J. Geophys. Res., 86:11815-11836.

Ewart, A., Bryan, W.B., and Gill, J., 1973. Mineralogy and geochemistry of the younger volcanic islands of Tonga, S.W. Pacific. J. Petrol., 14:429-465.

Grove, T.L., and Bryan, W.B., 1983. Fractionation of pyroxene-phyric MORB at low pressure: an experimental study. Contrib. Mineral. Petrol., 84:293-309.

Grove, T.L., and Kinzler, R.J., 1986. Petrogenesis of andesites. Earth Planet. Sci. Lett., 14:417-454.

Grove, T.L., Kinzler, R.J., and Bryan, W.B., 1990. Natural and experimental phase relations of lavas from Serocki Volcano. In Detrick, R., Honnorez, J., Bryan, W.B., Juteau, T., et al., Proc. ODP, Sci. Results, 106/109: College Station, TX (Ocean Drilling Program), 9-17.

Parson, L., Hawkins, J., Allan, J., et al., 1992. Proc. ODP, Init. Repts., 135: College Station, TX (Ocean Drilling Program).

Pearce, T.H., 1987. The identification and assessment of spurious trends in Pearce-type ratio variation diagrams: a discussion of some statistical arguments. Contrib. Mineral. Petrol., 97:529-534.

Reid, J., Steig, E., and Bryan, W.B., 1989. Major element evolution of basaltic magmas: a comparison of the information on CMAS and ALFE projections. Contrib. Mineral. Petrol., 101:318-325.

Schroeder, B., Thompson, G., Sulanowska, M., and Ludden, J.N., 1980 Analysis of geologic materials using an automated X-ray fluorescence system. X-ray Spectrom., 9:198-205.

Stanley, C.R., and Russell, J.K., 1989a. Pearce Plot: a Turbo-Pascal program for the analysis of rock compositions with Pearce element ratio diagrams. Comput. Geosci., 15:905-926.

1989b. Petrologic hypothesis testing with Pearce element ratio diagrams: derivation of diagram axes. Contrib. Mineral. Petrol., 103:78-89.

Tormey, D.R., Grove, T.L., and Bryan, W.B., 1987. Experimental petrology of normal MORB near the Kane Fracture Zone: $22^{\circ}-25^{\circ} \mathrm{N}$, mid-Atlantic Ridge. Contrib. Mineral. Petrol., 96:121-139.

Walker, D., Shibata, T., and DeLong, S.E., 1979. Abyssal tholeiites from the Oceanographer Fracture Zone. II. Phase equilibria and mixing. Contrib. Mineral. Petrol., 70:111-125.

\footnotetext{
-Abbreviations for names of organizations and publication titles in ODP reference lists follow the style given in Chemical Abstracts Service Source Index (published by American Chemical Society).
}

Date of initial receipt: 8 July 1992

Date of acceptance: 14 May 1993

Ms 135SR-134 